\title{
Carbazole-based small molecule electron donors: syntheses, characterization, and material properties
}

\author{
Roosa J. Sippola, ${ }^{\text {a }}$ Afshin Hadipour, ${ }^{\text {b }}$ Tuuva Kastinen,,${ }^{c}$ Paola Vivo, ${ }^{\text {c }}$ Terttu I. Hukka, ${ }^{\mathrm{c}}$ Tom \\ Aernouts, ${ }^{\text {b Juha P. Heiskanen*a }}$
}

${ }^{a}$ Research Unit of Sustainable Chemistry, University of Oulu, P.O. Box 3000, FI-90014 Oulu, Finland

${ }^{b}$ IMEC PV department, Kapeldreef 75, 3000 Leuven, Belgium

${ }^{c}$ Laboratory of Chemistry and Bioengineering, Tampere University of Technology, P.O. Box 541, FI-33101 Tampere,

Finland

juha.heiskanen@oulu.fi

\section{Graphical abstract}

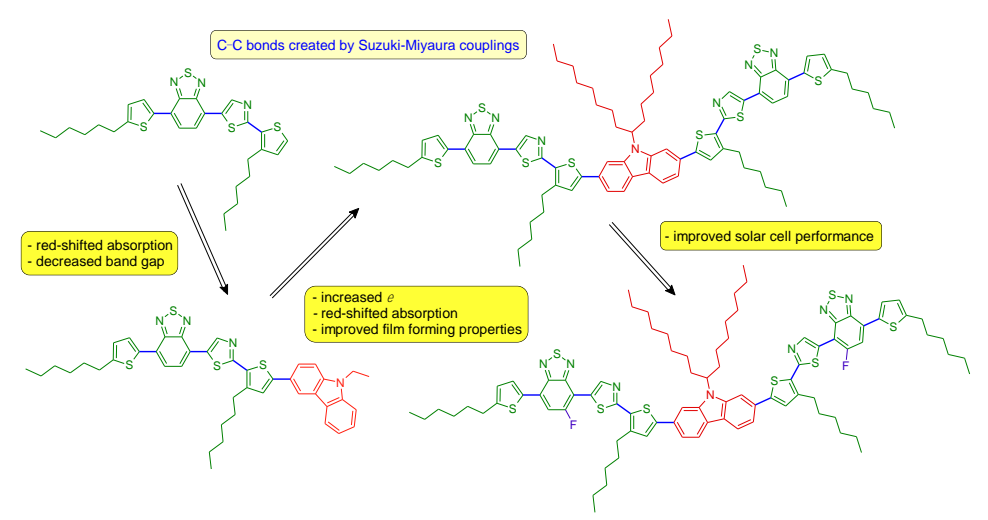

\section{Keywords}

Absorption, DFT, Electron donor, Organic solar cell, Suzuki-Miyaura, Synthesis

\section{Highlights}

-Novel $D-A$ and $A-D-A$ type small molecule electron donors were synthesized

-Characterization by computational, electrochemical, and spectroscopic methods

$\cdot A-D-A$ type materials were tested as active layer components in OSC devices

-Relations between molecular structures and properties are studied and discussed 


\begin{abstract}
Efficient synthetic methods for carbazole-based small molecule electron donors with donoracceptor $(D-A)$ and $A-D-A$ type structures were developed. In order to study the relation between chemical structures and material properties, the prepared compounds were characterized in detail using absorption spectroscopy, differential pulse voltammetry, and computational methods. In addition, symmetrical $A-D-A$ type compounds were tested as an active layer component in bulk heterojunction based organic solar cell (OSC) devices with conventional structure. The results show that the two compound types have many similar properties. However, the extended molecular structure of $A-D-A$ type compounds offer better film forming properties and higher molar absorption coefficients compared with the $D-A$ type materials. Furthermore, the attachment of fluoro substituents in the $A$ units has a positive effect on all solar cell device parameters. Moreover, the computational studies revealed that the molecular structures are twisted between the central carbazole $D$ unit and $\pi$-bridge which may result in inefficient intramolecular charge transfer and, also, relatively limited short-circuit currents in OSC devices.
\end{abstract}

\title{
1. Introduction
}

In the recent years, solution processed small molecule donors have attracted attention as alternatives to conjugated polymer-based donors in organic solar cells (OSCs). These materials show several advantages compared to their polymeric counterparts, such as well-defined structures without the end group contaminants, simple synthesis and purification, low dispersity, and excellent batchto-batch reproducibility $[1,2,3,4,5,6,7]$.

One of the most efficient structures of small molecule donor materials has turned out to be the $A-D-A$ type structure in which $A$ refers to an electron acceptor unit and $D$ refers to an electron donor unit. Often, these kinds of molecules are also termed push-pull-push type donor materials. By changing both the central $D$ and terminal $A$ units and a possible $\pi$-conjugation bridge in between the 
$A$ and $D$ units, desired material properties can be tailored and high power conversion efficiencies (PCEs) achieved [8]. For example, one of the best-performing small molecule donors is pDTS(FBTTh $)_{2}$ (Fig. 1) [5]. Up to 8.9\% PCE has been reported with this molecule by optimizing the OSC device structure [9]. Moreover, it has been demonstrated that some small molecule materials can produce very high PCEs both in bulk heterojunction (BHJ) based OSCs and in perovskite solar cells [10].

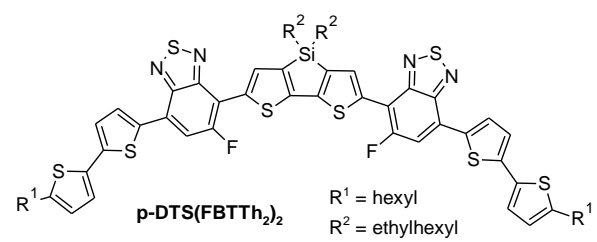

Fig. 1. The chemical structure of p-DTS(FBTTh $)_{2}$.

Especially, 2,1,3-benzothiadiazole (BT) unit and its substituted derivatives have been widely utilized as building blocks ( $A$ units) in both polymer and small molecule electron donor materials [11,12]. Moreover, various $D$ units have been studied as a component of OSC donor materials $[12,13]$. Carbazole $(\mathrm{Cz})$ has been employed as the $D$ unit in various semiconducting polymers and dye molecules $[14,15]$. The main advantage of the poly(2,7-carbazole)-based OSC devices is high open circuit voltages $\left(V_{o c}\right)$. Moreover, internal quantum efficiency can be close to $100 \%$ [16]. Few years ago, Cz-based small molecule materials showed promising results as donor components in BHJ OSCs $[17,18]$. Since then, small molecule materials containing $\mathrm{Cz}$ as the $D$ unit have gained growing interest and shown promising results. At least, three main structures $A-D-A[19,20], D-A[21,22]$, and $D-A-D[23,24,25,26]$ have been introduced. However, more experimental studies are needed to discover new state-of-the-art small molecule electron donors and, in particular, to gain systematic information about the relationships between their chemical structures, material properties, and performance in OSC applications.

Recently, we reported a synthetic pathway to BT-based building blocks [27]. Since then, we have further developed the synthetic strategy and, here, we present the syntheses of two 
unsymmetrical $D-A$ and two symmetrical $A-D-A$ type small molecules. In these compounds, $\mathrm{Cz}$ acts as a $D$ unit and either BT or its fluoro-substituted derivative as an $A$ unit. Thiophene and thiazole have been used as a $\pi$-bridge in between the $D$ and $A$ units. In order to find out how the changes in molecular structures affect the material properties, the prepared $D-A$ and $A-D-A$ type small molecule compounds have been characterized by spectroscopic, electrochemical, and computational methods. Moreover, the symmetrical $A-D-A$ type compounds have been tested as electron donor materials in BHJ-based OSC devices.

\section{Experimental section}

Commercial reagents were used as received. 2-(3-Hexylthiophen-2-yl)-5-(4,4,5,5tetramethyl-1,3,2-dioxaborolan-2-yl)thiazole and compound $\mathbf{3 b}$ were synthesized using the previously published methods [27]. The chemical structures of new compounds were characterized by using NMR and HRMS techniques. Melting points (reported as peak values) of compounds 5a, $\mathbf{5 b}, \mathbf{6 a}$, and $\mathbf{6 b}$ were measured by using Mettler Toledo DSC 1 apparatus with a TSO800GC1 Gas Control system. Samples of 1.6-2.2 mg were placed in $40 \mu \mathrm{L} \mathrm{Al} \mathrm{crucibles} \mathrm{with} \mathrm{pierced} \mathrm{lids.} \mathrm{The} \mathrm{DSC}$ scans were carried out from $5{ }^{\circ} \mathrm{C}$ to $300{ }^{\circ} \mathrm{C}$ at the heating rate of $20{ }^{\circ} \mathrm{C} \mathrm{min}{ }^{-1}$ under a nitrogen flow of $60 \mathrm{~mL} \mathrm{~min}^{-1}$.

\subsection{Syntheses}

2.1.1. Synthesis of 4-bromo-5-fluoro-7-(5-hexylthiophen-2-yl)-2,1,3-benzothiadiazole (2)

Toluene (6 mL), DMA (6 mL), distilled water (1.5 mL), and 5-hexyl-2-thiopheneboronic acid pinacol ester (1.02 equiv, $140.6 \mathrm{mg}, 0.48 \mathrm{mmol}$ ) were deoxygenated with argon for $15 \mathrm{~min}$ in a reaction tube with a magnetic stirring bar. 4,7-Dibromo-5-fluoro-2,1,3-benzothiadiazole (1) (146.9 $\mathrm{mg}, 0.47 \mathrm{mmol}), \mathrm{Cs}_{2} \mathrm{CO}_{3}(2.5$ equiv, $384.1 \mathrm{mg}, 1.18 \mathrm{mmol}), \mathrm{Pd}(\mathrm{OAc})_{2}(2.6 \mathrm{~mol} \%, 2.8 \mathrm{mg}, 12 \mu \mathrm{mol})$, and Xantphos $(2.6 \mathrm{~mol} \%, 6.8 \mathrm{mg}, 12 \mu \mathrm{mol})$ were added. The sealed tube was evacuated and backfilled with argon five times. The reaction mixture was stirred and heated in an oil bath $\left(60^{\circ} \mathrm{C}\right)$ for $3 \mathrm{~h}$. The 
reaction mixture was filtered through a thin pad of silica gel rinsing with toluene and evaporated under reduced pressure. The product was purified by using flash chromatography $\left(\mathrm{SiO}_{2}\right.$, toluene 1 : $1 n$-heptane). The isolated product 2 was collected as a yellow solid $(186.7 \mathrm{mg})$ in $>99 \%$ yield. $\mathrm{Mp}$

$90{ }^{\circ} \mathrm{C} .{ }^{1} \mathrm{H}$ NMR $\left(400 \mathrm{MHz}, \mathrm{CDCl}_{3}\right) \delta \mathrm{ppm} 0.91(\mathrm{t}, J=6.9 \mathrm{~Hz}, 3 \mathrm{H}), 1.32-1.38(\mathrm{~m}, 4 \mathrm{H}), 1.38-1.46(\mathrm{~m}$, 2H), 1.75 (quin, $J=7.5 \mathrm{~Hz}, 2 \mathrm{H}), 2.89$ (t, $J=7.7 \mathrm{~Hz}, 2 \mathrm{H}), 6.88(\mathrm{~d}, J=3.7 \mathrm{~Hz}, 1 \mathrm{H}), 7.62(\mathrm{~d}, J=10.0 \mathrm{~Hz}$, 1H), 7.95 (d, J=3.7 Hz, 1H). HRMS (ESI+, TOF) m/z: $[\mathrm{M}+\mathrm{H}]^{+}$Calcd for $\mathrm{C}_{16} \mathrm{H}_{17} \mathrm{~N}_{2} \mathrm{~S}_{2} \mathrm{BrF} 399.0001$; Found 398.9999.

\subsubsection{Synthesis of compound $3 a$}

Toluene (2.5 mL), DMA (2.5 mL), and distilled water $(0.5 \mathrm{~mL})$ were deoxygenated with argon for $15 \mathrm{~min}$ in a reaction tube with a magnetic stirring bar. Compound 2 (99.9 $\mathrm{mg}, 0.25 \mathrm{mmol})$, 2-(3hexylthiophen-2-yl)-5-(4,4,5,5-tetramethyl-1,3,2-dioxaborolan-2-yl)thiazole (1.04 equiv, $99.2 \mathrm{mg}$, $0.26 \mathrm{mmol}), \mathrm{Cs}_{2} \mathrm{CO}_{3}(2.5$ equiv, $204.9 \mathrm{mg}, 0.63 \mathrm{mmol}), t-\mathrm{Bu}_{3} \mathrm{P} \cdot \mathrm{HBF}_{4}(12 \mathrm{~mol} \%, 8.7 \mathrm{mg}, 30 \mu \mathrm{mol})$ and $\mathrm{Pd}_{2}(\mathrm{dba})_{3}(3 \mathrm{~mol} \%, 6.9 \mathrm{mg}, 7.5 \mu \mathrm{mol})$ were added. The sealed tube was evacuated and backfilled with argon five times. The reaction mixture was stirred and heated in an oil bath $\left(90^{\circ} \mathrm{C}\right)$ for $21 \mathrm{~h}$. The reaction mixture was filtered through a thin pad of silica gel rinsing with toluene and evaporated under reduced pressure. The product was purified by using flash chromatography $\left(\mathrm{SiO}_{2}\right.$, toluene). The isolated product 3a was collected as a red solid (100.4 mg) in $70 \%$ yield. Mp $79{ }^{\circ} \mathrm{C} .{ }^{1} \mathrm{H}$ NMR $\left(400 \mathrm{MHz}, \mathrm{CDCl}_{3}\right) \delta$ ppm 0.90-0.94 (m, 6H), 1.33-1.54 (m, 12H), 1.73-1.81 (m, 4H), $2.90(\mathrm{t}, J=7.6$ Hz, 2H), 3.05 (t, J=7.9 Hz, 2H), 6.90 (d, J=3.7 Hz, 1H), 7.02 (d, J=5.1 Hz, 1H), 7.35 (d, J=5.1 Hz, 1H), $7.70(\mathrm{~d}, J=13.0 \mathrm{~Hz}, 1 \mathrm{H}), 8.00(\mathrm{~d}, J=3.7 \mathrm{~Hz}, 1 \mathrm{H}), 8.90$ (s, 1H). HRMS (ESI+, TOF) m/z: [M+H] ${ }^{+}$ Calcd for $\mathrm{C}_{29} \mathrm{H}_{33} \mathrm{~N}_{3} \mathrm{~S}_{4} \mathrm{~F}$ 570.1541; Found 570.1534.

\subsubsection{Synthesis of compound $\mathbf{4 a}$}

Compound 3a (80.2 mg, $0.14 \mathrm{mmol})$ was dissolved in $\mathrm{CH}_{2} \mathrm{Cl}_{2}(10 \mathrm{~mL})$ and NBS (1.1 equiv, $27.8 \mathrm{mg}, 0.16 \mathrm{mmol}$ ) was added. The reaction mixture was stirred at room temperature for $20 \mathrm{~h}$. The 
solvent was evaporated and the crude product was subjected to flash chromatography $\left(\mathrm{SiO}_{2}\right.$, toluene). The pure compound $4 \mathbf{a}$ was isolated as a red solid $(80.0 \mathrm{mg})$ in $88 \%$ yield. Mp $96{ }^{\circ} \mathrm{C} .{ }^{1} \mathrm{H}$ NMR $(400$ $\left.\mathrm{MHz}, \mathrm{CDCl}_{3}\right) \delta \mathrm{ppm} 0.90-0.95(\mathrm{~m}, 6 \mathrm{H}), 1.32-1.51(\mathrm{~m}, 12 \mathrm{H}), 1.69-1.80(\mathrm{~m}, 4 \mathrm{H}), 2.90(\mathrm{t}, J=7.6 \mathrm{~Hz}$, 2H), 2.95 (t, J=7.8 Hz, 2H), 6.89 (d, J=3.7 Hz, 1H), 6.96 (s, 1H), 7.67 (d, J=13.0 Hz, 1H), 7.98 (d, $J=3.7 \mathrm{~Hz}, 1 \mathrm{H}), 8.84(\mathrm{~s}, 1 \mathrm{H})$. HRMS (ESI+, TOF) m/z: $[\mathrm{M}+\mathrm{H}]^{+}$Calcd for $\mathrm{C}_{29} \mathrm{H}_{32} \mathrm{~N}_{3} \mathrm{~S}_{4} \mathrm{BrF} 648.0646$; Found 648.0643.

\subsubsection{Synthesis of compound $\mathbf{4 b}$}

The synthesis was carried out using the same procedure as for compound $\mathbf{4 a}$. The specific amounts of reagents used were: compound $\mathbf{3 b}(71.7 \mathrm{mg}, 0.130 \mathrm{mmol})$, NBS (1.02 equiv, $23.5 \mathrm{mg}$, $0.132 \mathrm{mmol})$, and $\mathrm{CH}_{2} \mathrm{Cl}_{2}(4.8 \mathrm{~mL})$. Pure compound $\mathbf{4 b}$ was isolated as a red solid $(42.9 \mathrm{mg})$ in $52 \%$ yield. Mp $130{ }^{\circ} \mathrm{C} .{ }^{1} \mathrm{H}$ NMR $\left(400 \mathrm{MHz}, \mathrm{CDCl}_{3}\right) \delta \mathrm{ppm} 0.90-0.95(\mathrm{~m}, 6 \mathrm{H}), 1.32-1.51(\mathrm{~m}, 12 \mathrm{H}), 1.70$ $1.80(\mathrm{~m}, 4 \mathrm{H}), 2.90(\mathrm{t}, J=7.7 \mathrm{~Hz}, 2 \mathrm{H}), 2.96(\mathrm{t}, J=7.8 \mathrm{~Hz}, 2 \mathrm{H}), 6.90(\mathrm{~d}, J=3.8 \mathrm{~Hz}, 1 \mathrm{H}), 6.97(\mathrm{~s}, 1 \mathrm{H})$, $7.82(\mathrm{~d}, J=7.6 \mathrm{~Hz}, 1 \mathrm{H}), 7.85(\mathrm{~d}, J=7.6 \mathrm{~Hz}, 1 \mathrm{H}), 7.99(\mathrm{~d}, J=3.8 \mathrm{~Hz}, 1 \mathrm{H}), 8.69(\mathrm{~s}, 1 \mathrm{H}) .{ }^{13} \mathrm{C} \mathrm{NMR}(100.6$ $\left.\mathrm{MHz}, \mathrm{CDCl}_{3}\right) \delta$ ppm 14.1, 14.1, 22.6, 22.6, 28.8, 29.2, 29.8, 30.2, 30.3, 31.6, 31.6, 114.8, 122.3, 124.8, 125.4, 126.4, 127.2, 128.1, 133.2, 133.5, 134.1, 136.4, 141.7, 142.8, 148.6, 152.3, 152.5, 159.9. HRMS (ESI+, TOF) m/z: [M+H] ${ }^{+}$Calcd for $\mathrm{C}_{29} \mathrm{H}_{33} \mathrm{~N}_{3} \mathrm{~S}_{4} \mathrm{Br}$ 630.0741; Found 630.0746. A small amount of byproduct 7 was isolated for analyses. $\mathrm{Mp} 90{ }^{\circ} \mathrm{C} .{ }^{1} \mathrm{H} \mathrm{NMR}\left(400 \mathrm{MHz}, \mathrm{CDCl}_{3}\right) \delta \mathrm{ppm} 0.90$ $0.94(\mathrm{~m}, 6 \mathrm{H}), 1.32-1.51(\mathrm{~m}, 12 \mathrm{H}), 1.70-1.79(\mathrm{~m}, 4 \mathrm{H}), 2.87(\mathrm{t}, J=7.5 \mathrm{~Hz}, 2 \mathrm{H}), 2.96(\mathrm{t}, J=7.8 \mathrm{~Hz}, 2 \mathrm{H})$, $6.88(\mathrm{~s}, 1 \mathrm{H}), 6.98(\mathrm{~s}, 1 \mathrm{H}), 7.93(\mathrm{~d}, J=7.6 \mathrm{~Hz}, 1 \mathrm{H}), 8.07(\mathrm{~d}, J=7.6 \mathrm{~Hz}, 1 \mathrm{H}), 8.74(\mathrm{~s}, 1 \mathrm{H}) .{ }^{13} \mathrm{C}$ NMR $\left(100.6 \mathrm{MHz}, \mathrm{CDCl}_{3}\right) \delta$ ppm 14.1, 14.1, 22.6, 22.6, 28.8, 29.2, 29.7, 30.2, 30.2, 31.1, 31.5, 31.6, 109.5, $115.0,124.2,125.5,125.8,128.3,129.8,129.9,133.3,133.5,133.7,142.3,143.0,148.2,152.0,153.5$, 160.4. HRMS (ESI+, TOF) m/z: [M+H] $]^{+}$Calcd for $\mathrm{C}_{29} \mathrm{H}_{32} \mathrm{~N}_{3} \mathrm{~S}_{4} \mathrm{Br}_{2}$ 707.9846; Found 707.9836.

\subsubsection{Synthesis of compound 5 a}


Toluene (2.25 mL), DMA (2.25 mL), and distilled water $(0.5 \mathrm{~mL})$ were deoxygenated with argon for $15 \mathrm{~min}$ in a reaction tube with a magnetic stirring bar. Compound $\mathbf{4 a}(75.9 \mathrm{mg}, 0.117 \mathrm{mmol})$, 9-ethylcarbazole-3-boronic acid (1.05 equiv, $29.3 \mathrm{mg}, 0.123 \mathrm{mmol}$ ), $\mathrm{Cs}_{2} \mathrm{CO}_{3}$ (2.5 equiv, $96.1 \mathrm{mg}$, $0.29 \mathrm{mmol}), \mathrm{Pd}(\mathrm{OAc})_{2}(6 \mathrm{~mol} \%, 1.5 \mathrm{mg}, 6.7 \mu \mathrm{mol})$, and Xantphos (5 mol\%, $\left.3.4 \mathrm{mg}, 5.9 \mu \mathrm{mol}\right)$ were added. The sealed tube was evacuated and backfilled with argon five times. The reaction mixture was stirred and heated in an oil bath $\left(100^{\circ} \mathrm{C}\right)$ for $1.5 \mathrm{~h}$. The reaction mixture was filtered through a thin pad of silica gel rinsing with toluene and evaporated under reduced pressure. The product was purified by using flash chromatography $\left(\mathrm{SiO}_{2}\right.$, toluene). The solid product was boiled in acetone-methanol mixture (1:2), cooled to room temperature, filtered and washed with acetone-methanol mixture several times. The isolated product 5a was collected as a deep dark red solid ( $87.2 \mathrm{mg})$ in $98 \%$ yield. Mp $102{ }^{\circ} \mathrm{C} .{ }^{1} \mathrm{H}$ NMR (400 MHz, $\left.\mathrm{CD}_{2} \mathrm{Cl}_{2}\right) \delta$ ppm 0.91-0.98 (m, 6H), 1.33-1.49 (m, 13H), 1.57 (quin, $J=7.1 \mathrm{~Hz}, 2 \mathrm{H}$ ), 1.75 (quin, $J=7.5 \mathrm{~Hz}, 2 \mathrm{H}$ ), 1.84 (quin, $J=7.6 \mathrm{~Hz}, 2 \mathrm{H}$ ), 2.88 (t, $J=7.6 \mathrm{~Hz}, 2 \mathrm{H}$ ), 3.04 (t, $J=7.8 \mathrm{~Hz}, 2 \mathrm{H}), 4.35(\mathrm{q}, J=7.2 \mathrm{~Hz}, 2 \mathrm{H}), 6.87(\mathrm{~d}, J=3.7 \mathrm{~Hz}, 1 \mathrm{H}), 7.24-7.28(\mathrm{~m}, 2 \mathrm{H}), 7.39-7.43$ (m, 2H), 7.47-7.51 (m, 1H), $7.65(\mathrm{~d}, J=13.1 \mathrm{~Hz}, 1 \mathrm{H}), 7.75(\mathrm{dd}, J=8.6,1.8 \mathrm{~Hz}, 1 \mathrm{H}), 7.95(\mathrm{~d}, J=3.7 \mathrm{~Hz}$, 1H), $8.12(\mathrm{~d}, J=7.6 \mathrm{~Hz}, 1 \mathrm{H}), 8.34(\mathrm{~d}, J=1.4 \mathrm{~Hz}, 1 \mathrm{H}), 8.84$ (s, 1H). HRMS (ESI+, TOF) m/z: [M+H] ${ }^{+}$ Calcd for $\mathrm{C}_{43} \mathrm{H}_{44} \mathrm{~N}_{4} \mathrm{~S}_{4} \mathrm{~F} 763.2433$; Found 763.2441.

\subsubsection{Synthesis of compound $\mathbf{5 b}$}

The synthesis was carried out using the same procedure as for compound 5a. The specific amounts of reagents used were: toluene $(1.5 \mathrm{~mL})$, DMA $(1.5 \mathrm{~mL})$, distilled water $(0.38 \mathrm{~mL})$, compound 4b (50.2 mg, $0.080 \mathrm{mmol})$, 9-ethylcarbazole-3-boronic acid (1.04 equiv, $19.9 \mathrm{mg}, 0.083$ mmol), $\mathrm{Cs}_{2} \mathrm{CO}_{3}(2.5$ equiv, $64.8 \mathrm{mg}, 0.20 \mathrm{mmol}), \mathrm{Pd}(\mathrm{OAc})_{2}(8 \mathrm{~mol} \%, 1.5 \mathrm{mg}, 6.7 \mu \mathrm{mol})$, and Xantphos (5 mol\%, $2.5 \mathrm{mg}, 4.3 \mu \mathrm{mol})$. Pure compound $\mathbf{5 b}$ was isolated as a dark red solid (57.1 $\mathrm{mg})$ in $96 \%$ yield. $\mathrm{Mp} 178{ }^{\circ} \mathrm{C} .{ }^{1} \mathrm{H}$ NMR $\left(400 \mathrm{MHz}, \mathrm{CD}_{2} \mathrm{Cl}_{2}\right) \delta$ ppm 0.91-0.97 (m, 6H), 1.34-1.48 (m, 13H), 1.58 (quin, $J=7.3 \mathrm{~Hz} 2 \mathrm{H}$ ), 1.77 (quin, $J=7.5 \mathrm{~Hz}, 2 \mathrm{H}$ ), 1.86 (quin, $J=7.6 \mathrm{~Hz}, 2 \mathrm{H}$ ), 2.91 (t, $J=7.6$ $\mathrm{Hz}, 2 \mathrm{H}), 3.08$ (t, J=8.0 Hz, 2H), 4.40 (q, J=7.2 Hz, 2H), 6.91 (d, J=3.7 Hz, 1H), 7.25-7.32 (m, 2H), 
7.45-7.53 (m, 3H), 7.80 (dd, J=8.6, 1.8 Hz, 1H), 7.83 (d, J=7.6 Hz, 1H), 7.87 (d, J=7.6 Hz, 1H), 7.99 (d, J=3.7 Hz, 1H), $8.16(\mathrm{~d}, J=7.7 \mathrm{~Hz}, 1 \mathrm{H}), 8.41(\mathrm{~d}, J=1.6 \mathrm{~Hz}, 1 \mathrm{H}), 8.75(\mathrm{~s}, 1 \mathrm{H}) .{ }^{13} \mathrm{C}$ NMR $(100.6$ $\left.\mathrm{MHz}, \mathrm{CDCl}_{3}\right) \delta$ ppm 13.8, 14.1, 14.1, 22.6, 22.7, 28.9, 29.5, 29.9, 30.3, 30.6, 31.6, 31.6, 31.8, 37.7, $108.7,108.8,117.7,119.3,120.6,122.8,122.9,123.5,123.9,124.8,124.9,125.2,125.3,126.1,126.7$, $127.9,129.9,133.3,136.6,139.9,140.5,142.0,143.9,146.6,148.3,152.4,152.5,161.3$. HRMS (ESI+, TOF) m/z: $[\mathrm{M}+\mathrm{H}]^{+}$Calcd for $\mathrm{C}_{43} \mathrm{H}_{45} \mathrm{~N}_{4} \mathrm{~S}_{4}$ 745.2527; Found 745.2524.

\subsubsection{Synthesis of compound $\mathbf{6 a}$}

Toluene (3 mL), DMA (3 mL), and distilled water $(0.6 \mathrm{~mL})$ were deoxygenated with argon for $15 \mathrm{~min}$ in a reaction tube with a magnetic stirring bar. Compound $\mathbf{4 a}$ (2.05 equiv, $98.7 \mathrm{mg}, 0.152$ mmol), 9-(9-heptadecanyl)-2,7-bis(4,4,5,5-tetramethyl-1,3,2-dioxaborolan-2-yl)carbazole (48.8 mg, $0.074 \mathrm{mmol}), \mathrm{Cs}_{2} \mathrm{CO}_{3}(5$ equiv, $124.0 \mathrm{mg}, 0.381 \mathrm{mmol}), \mathrm{Pd}(\mathrm{OAc})_{2}(10 \mathrm{~mol} \%, 1.7 \mathrm{mg}, 7.6 \mu \mathrm{mol})$, and Xantphos $(10 \mathrm{~mol} \%, 4.4 \mathrm{mg}, 7.6 \mu \mathrm{mol})$ were added. The sealed tube was evacuated and backfilled with argon five times. The reaction mixture was stirred and heated in an oil bath $\left(100{ }^{\circ} \mathrm{C}\right)$ for $4 \mathrm{~h}$. The reaction mixture was filtered through a thin pad of silica gel rinsing with $\mathrm{CHCl}_{3}$ and evaporated under reduced pressure. The product was purified by using flash chromatography $\left(\mathrm{SiO}_{2}, \mathrm{CHCl}_{3}\right)$. The solid product was boiled in acetone $(3 \mathrm{~mL})$, filtered and washed with hot acetone $(9 \mathrm{~mL})$. The procedure was repeated four times. The isolated product $6 \mathbf{a}$ was collected as a deep dark solid (109.3 $\mathrm{mg})$ in $96 \%$ yield. $\mathrm{Mp} 156{ }^{\circ} \mathrm{C} .{ }^{1} \mathrm{H} \mathrm{NMR}\left(400 \mathrm{MHz}, \mathrm{CDCl}_{3}\right.$, at $\left.330 \mathrm{~K}\right) \delta \mathrm{ppm} 0.80-0.84$ (t, J=6.6, 6H), 0.92$0.99(\mathrm{~m}, 12 \mathrm{H}), 1.14-1.50(\mathrm{~m}, 44 \mathrm{H})$ [28], 1.60 (quin, $J=7.3 \mathrm{~Hz}, 4 \mathrm{H}), 1.79$ (quin, $J=7.3 \mathrm{~Hz}, 4 \mathrm{H}$ ), 1.89 (quin, $J=7.6 \mathrm{~Hz}, 4 \mathrm{H}), 2.01-2.10(\mathrm{~m}, 2 \mathrm{H}), 2.34-2.44(\mathrm{~m}, 2 \mathrm{H}), 2.92(\mathrm{t}, J=7.5 \mathrm{~Hz}, 4 \mathrm{H}), 3.12(\mathrm{t}, J=7.6$ $\mathrm{Hz}, 4 \mathrm{H}), 4.66(\mathrm{tt}, J=9.7,4.9 \mathrm{~Hz}, 1 \mathrm{H}), 6.91(\mathrm{~d}, J=3.7 \mathrm{~Hz}, 2 \mathrm{H}), 7.33(\mathrm{~s}, 2 \mathrm{H}), 7.56(\mathrm{~d}, J=8.1 \mathrm{~Hz}, 2 \mathrm{H})$, $7.72(\mathrm{~d}, J=12.8 \mathrm{~Hz}, 2 \mathrm{H}), 7.80$ (br s, 2H), 8.02 (d, J=3.7 Hz, 2H), 8.07 (d, J=8.1 Hz, 2H), 8.94 (s, 2H). HRMS (ESI+, TOF) m/z: [M+H] ${ }^{+}$Calcd for $\mathrm{C}_{87} \mathrm{H}_{104} \mathrm{~N}_{7} \mathrm{~F}_{2} \mathrm{~S}_{8}$ 1540.6087; Found 1540.6097.

\subsubsection{Synthesis of compound $\mathbf{6} \boldsymbol{b}$}


The synthesis was carried out using the same procedure as for compound 6a. The specific amounts of reagents used were: toluene (2.2 mL), DMA $(2.2 \mathrm{~mL})$, distilled water $(0.4 \mathrm{~mL})$, compound 4b (2 equiv, $70.2 \mathrm{mg}, \quad 0.11 \mathrm{mmol})$, 9-(9-heptadecanyl)-2,7-bis(4,4,5,5-tetramethyl-1,3,2dioxaborolan-2-yl)carbazole (35.9 mg, $0.055 \mathrm{mmol}$ ), $\mathrm{Cs}_{2} \mathrm{CO}_{3}$ (5 equiv, $90.2 \mathrm{mg}, 0.277 \mathrm{mmol}$ ), $\operatorname{Pd}(\mathrm{OAc})_{2}(11 \mathrm{~mol} \%, 1.4 \mathrm{mg}, 6.2 \mu \mathrm{mol})$, and Xantphos $(10 \mathrm{~mol} \%, 3.2 \mathrm{mg}, 5.6 \mu \mathrm{mol})$. The isolated product $6 \mathbf{b}$ was collected as a deep dark solid $(64.3 \mathrm{mg})$ in $78 \%$ yield. Mp $159{ }^{\circ} \mathrm{C} .{ }^{1} \mathrm{H}$ NMR (400 $\mathrm{MHz}, \mathrm{CDCl}_{3}$, at $\left.325 \mathrm{~K}\right) \delta \mathrm{ppm} 0.79(\mathrm{t}, J=6.9 \mathrm{~Hz}, 6 \mathrm{H}), 0.89-0.96(\mathrm{~m}, 12 \mathrm{H}), 1.17-1.23(\mathrm{~m}, 18 \mathrm{H}), 1.29-$ $1.36(\mathrm{~m}, 14 \mathrm{H}), 1.39-1.47(\mathrm{~m}, 12 \mathrm{H}), 1.56$ (quin, $J=7.2 \mathrm{~Hz}, 4 \mathrm{H}), 1.75$ (quin, $J=7.5 \mathrm{~Hz}, 4 \mathrm{H}$ ), 1.84 (quin, $J=7.6 \mathrm{~Hz}, 4 \mathrm{H}), 1.99-2.07(\mathrm{~m}, 2 \mathrm{H}), 2.32-2.41(\mathrm{~m}, 2 \mathrm{H}), 2.87(\mathrm{t}, J=7.6 \mathrm{~Hz}, 4 \mathrm{H}), 3.05(\mathrm{t}, J=7.7 \mathrm{~Hz}, 4 \mathrm{H})$, $4.63(\mathrm{tt}, J=9.7,5.0 \mathrm{~Hz}, 1 \mathrm{H}), 6.85(\mathrm{~d}, J=3.7 \mathrm{~Hz}, 2 \mathrm{H}), 7.27(\mathrm{~s}, 2 \mathrm{H}), 7.50(\mathrm{~d}, J=8.1 \mathrm{~Hz}, 2 \mathrm{H}), 7.68-7.80$ $(\mathrm{m}, 6 \mathrm{H}), 7.95(\mathrm{~d}, J=3.7 \mathrm{~Hz}, 2 \mathrm{H}), 8.01(\mathrm{~d}, J=8.1 \mathrm{~Hz}, 2 \mathrm{H}), 8.73(\mathrm{~s}, 2 \mathrm{H}) .{ }^{13} \mathrm{C} \mathrm{NMR}\left(100.6 \mathrm{MHz}, \mathrm{CDCl}_{3}\right.$, at $325 \mathrm{~K}) \delta$ ppm 14.0, 14.0, 14.1, 22.6, 22.7, 27.0, 28.9, 29.2, 29.4, 29.4, 29.5, 30.0, 30.4, 30.6, 31.6, 31.6, 31.8, 31.8, 34.0, 56.9, 106.3, 108.9, 117.3, 120.7, 120.7, 122.8, 124.8, 125.3, 126.3, 126.4, $127.1,128.1,131.0,131.3,133.7,136.6,142.1,143.9,146.5,148.4,152.5,152.6,161.2$. HRMS (ESI+, TOF) m/z: $[\mathrm{M}+\mathrm{H}]^{+}$Calcd for $\mathrm{C}_{87} \mathrm{H}_{106} \mathrm{~N}_{7} \mathrm{~S}_{8}$ 1504.6275; Found 1504.6283.

\subsection{Spectroscopic measurements and electrochemical characterization}

The steady-state absorption spectra were measured with a Shimadzu UV-3600 UV/Vis/NIR spectrophotometer both in solution and in thin films. Thin films of the three compounds were deposited by spin-coating (WS-400B-6NPP/LITE, Laurell Technologies) from $\mathrm{CHCl}_{3}$ solution (2000 rpm, $2000 \mathrm{rpm} / \mathrm{s}, 1 \mathrm{~min}$ ) onto clean quartz substrates.

Differential pulse voltammetry (DPV), for HOMO/LUMO determination of the target compounds, was performed by employing a potentiostat (Compact-Stat, Ivium Technologies) and a three-electrode cell configuration. Dry tetrabutyl ammonium tetrafluoroborate in dichloromethane $(0.1 \mathrm{M})$ was the supporting electrolyte, glass platinum electrode the working electrode, Pt wire the 
counter-electrode, and $\mathrm{Ag} / \mathrm{AgCl}$ wire the pseudo-reference electrode. Ferrocene/ferrocenium $(\mathrm{Fc} / \mathrm{Fc}+)$ couple was used as an internal standard reference to scale the measured potentials against the vacuum level [29]. All solutions were deoxygenated with $\mathrm{N}_{2}$ prior to each experiment. The measurements were carried out between $-2.4 \mathrm{~V}$ and $1.6 \mathrm{~V}$, scanning in both directions with scan rate of $50 \mathrm{mV} / \mathrm{s}$ The HOMO and LUMO energy levels were calculated from the oxidation potentials observed from the DPV curves according to the equations:

$$
\begin{aligned}
& E_{\text {HOMO }}(\mathrm{eV})=-\left(E_{\mathrm{Ox}}-\mathrm{E}_{\mathrm{Fc} / \mathrm{Fc}+}\right)-4.80 \mathrm{eV} \\
& \mathrm{E}_{\mathrm{LUMO}}(\mathrm{eV})=\left(\mathrm{E}_{\mathrm{red}}-\mathrm{E}_{\mathrm{Fc} / \mathrm{Fc}+}\right)-4.80 \mathrm{eV}
\end{aligned}
$$

where $\mathrm{E}_{\mathrm{ox}}$ and $\mathrm{E}_{\mathrm{red}}$ are the oxidation and reduction potentials of the sample and $\mathrm{E}_{\mathrm{Fc} / \mathrm{Fc}+}$ the potential of ferrocene. $\mathrm{E}_{\mathrm{ox}}$ and $\mathrm{E}_{\mathrm{Fc} / \mathrm{Fc}+}$ are both referred against the $\mathrm{Ag} / \mathrm{AgCl}$ reference electrode. The value -4.80 $\mathrm{eV}$ is the energy level of ferrocene against vacuum [30].

\subsection{Computations}

All the calculations were carried out with the Gaussian 09 (Revision D.01) suite of programs [31]. The optimal dihedral angles (see Fig. S4) between adjoining units present in compounds $\mathbf{5 a}, \mathbf{5 b}$, 6a, and $6 \mathbf{b}$ were determined with the relaxed potential energy scans (PES) at $5^{\circ}$ intervals, i.e. the selected dihedral angle was fixed while optimizing the geometry of the two-unit-entity otherwise fully with the density functional theory (DFT) at the B3LYP $[32,33] / 6-31+\mathrm{G}^{* *}$ level of theory. Only two units of the whole molecules were included per a PES scan due to a computation demand of the diffuse basis set. In the PES studies, the ethyl and hexyl side chains were replaced with methyl groups. Additional conformational studies were also carried out for compounds $\mathbf{5 a}$ and $\mathbf{6 a}$ (see Supplementary material for further information). The dihedral angles of compounds $\mathbf{5 a}, \mathbf{5 b}, \mathbf{6 a}$, and $\mathbf{6 b}$ were set according to the PES scans and then the ground-state geometries of the whole molecules with the longer ethyl and hexyl side chains (Scheme 2) were optimized both in vacuum and chloroform at the B3LYP/6-31G** level of theory. Solvation effects were taken into account by means of the integral equation formalism of the polarizable continuum model using the dielectric constant of 4.71 for 
chloroform [34,35]. The final optimized geometries (Fig. 3) were confirmed at the same level of theory to be the minimum energy structures by the absence of the imaginary frequency. The vertical transition energies and oscillator strengths of the compounds were determined both in vacuum and chloroform with TDDFT for the first 20 excited states at the $\omega \mathrm{B} 97 \mathrm{XD} / 6-31 \mathrm{G}^{* *}$ levels of theory. The solvent TDDFT calculations were carried out using the geometries optimized in chloroform. The electronic transitions were qualitatively described using NTOs as a representation for the transition density matrix [36]. Pictorial data for the geometries, absorption spectra, and NTOs were generated using Chemcraft 1.8.

\subsection{Solar cell preparation and characterization}

All OSCs with a conventional device structure were fabricated onto detergent and solvent cleaned $150 \mathrm{~nm}$ thick ITO coated glass substrates (Colorado Concept). $\mathrm{MoO}_{3}$ layers $(5 \mathrm{~nm}$ ) were deposited by thermal evaporation on the top of glass/ITO substrates in a vacuum chamber with base

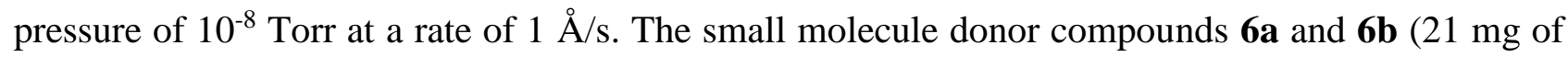
donor) were blended with either $\mathrm{PC}_{60} \mathrm{BM}$ or $\mathrm{PC}_{70} \mathrm{BM}$ (Nano-C) fullerene acceptor material (14 mg) in 1.5:1 weight ratio in $1 \mathrm{~mL}$ of a solvent mixture at $60{ }^{\circ} \mathrm{C}$ for 1 hour. The solvent mixture was prepared by mixing $19.92 \mathrm{~mL}$ of chlorobenzene with $80 \mu \mathrm{L}$ of solvent additive 1,8-diiodooctane (Sigma-Aldrich). The $80 \mathrm{~nm}$ thick BHJ active layers were processed using spin coating (1400 rpm for 60 seconds). The thicknesses of the active layers were measured by a Dektak $6 \mathrm{M}$ profilometer. After the spin coating, the devices were subsequently annealed at $100{ }^{\circ} \mathrm{C}$ for $10 \mathrm{~min}$ to remove possible residual solvents. The device structures were completed with thermally evaporated $20 \mathrm{~nm}$ thick calcium $(\mathrm{Ca})$ layers covered with $150 \mathrm{~nm}$ thick silver $(\mathrm{Ag})$ layer acting as the cathode. The $\mathrm{Ca}$ and Ag layers were deposited via thermal evaporation in a vacuum chamber with base pressure of $10^{-}$

${ }^{8}$ Torr at rates of $3 \AA / s$ and $6 \AA / s$, respectively. All processing steps were done inside the $\mathrm{N}_{2}$ filled glove box. The active area of the OSC devices in all cases were $0.13 \mathrm{~cm}^{2}$. Current density-voltage 
characteristics of the prepared OSCs were measured in dark and under simulated solar light, using a Keithley 2602A in combination with an Abet solar simulator, calibrated to produce $100 \mathrm{~mW} / \mathrm{cm}^{2}$ AM1.5G illumination. All device measurements were performed in a $\mathrm{N}_{2}$ environment and at room temperature. For each sample, the current-voltage measurement data is presented as average of 12 cells with error bars (standard deviations) in Figures S4 and S5 in the Supplementary material. The results are reported as the values of the best cells in Figure 6.

\section{Results and Discussion}

\subsection{Syntheses}

Compound $\mathbf{2}$ has previously been synthesized from compound $\mathbf{1}$ in $50 \%$ yield using Stille cross-coupling approach [37]. We found that a regioselective Suzuki-Miyaura cross-coupling between compound $\mathbf{1}$ and 5-hexyl-2-thiopheneboronic acid pinacol ester occurs in the presence of $\mathrm{Pd}(\mathrm{OAc})_{2} / \mathrm{Xantphos}$ catalyst system. Moreover, the desired compound $\mathbf{2}$ was collected in quantitative

yield (Scheme 1). The structure of compound 2 was confirmed by ${ }^{1} \mathrm{H} 1 \mathrm{D}$ and ${ }^{1} \mathrm{H}-{ }^{1} \mathrm{H} 2 \mathrm{D}$ NOE NMR experiments (see Supplementary material). At the next step, compound $\mathbf{2}$ was cross-coupled with 2(3-hexylthiophen-2-yl)-5-(4,4,5,5-tetramethyl-1,3,2-dioxaborolan-2-yl)thiazole [27] affording compound 3a in low 35\% yield in the presence of $\operatorname{Pd}(\mathrm{OAc})_{2}$ as a palladium source. The yield was improved up to $70 \%$ by the replacement of $\mathrm{Pd}(\mathrm{OAc})_{2}$ with $\mathrm{Pd}_{2}(\mathrm{dba})_{3}$.

Compounds 3a and 3b [27] were brominated with $\mathrm{N}$-bromosuccinimide (NBS) in $\mathrm{CH}_{2} \mathrm{Cl}_{2}$. Surprisingly, these two substrates showed quite different reactivity and selectivity in bromination. Compound 4a was isolated in good $88 \%$ yield, whereas the reaction with compound $\mathbf{3 b}$ gave a complicated mixture and the desired product $\mathbf{4 b}$ could be isolated only in $52 \%$ yield. The bromination of compound $\mathbf{3 b}$ also resulted in a dibrominated byproduct 7. 


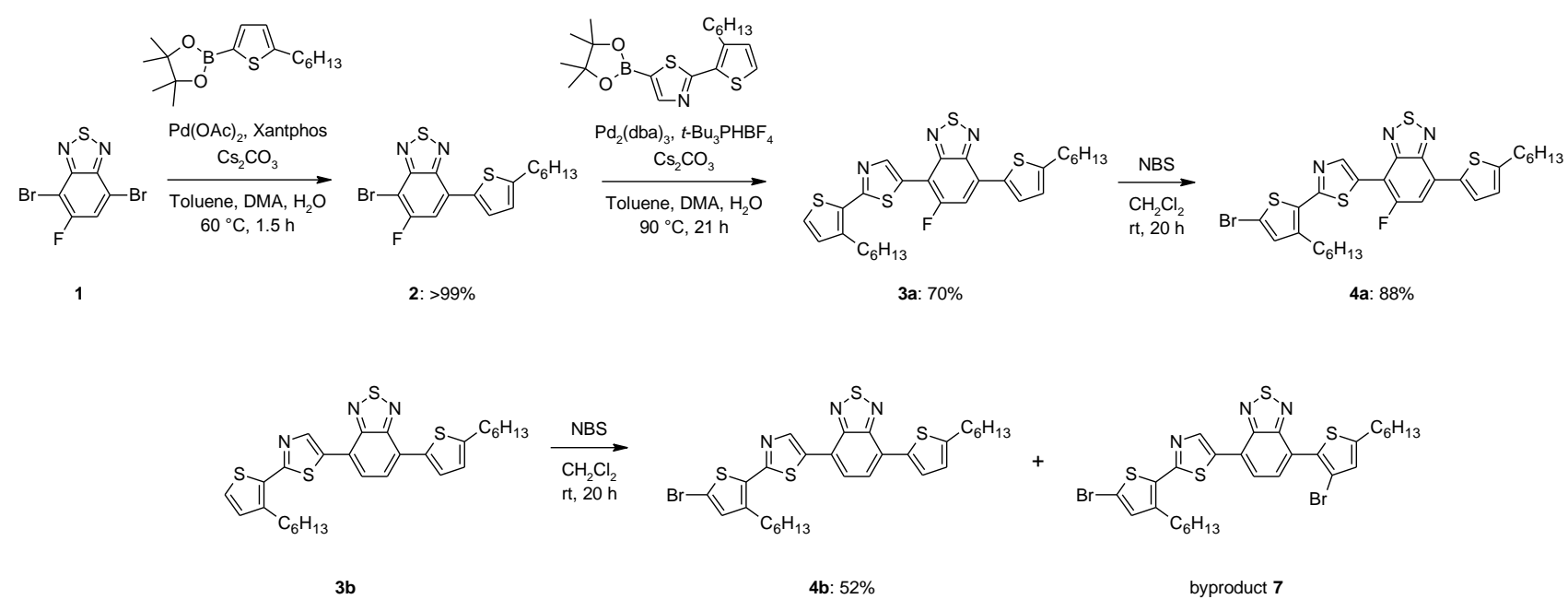

Scheme 1. Syntheses of the small molecule donor material building blocks

At the final stage, compounds $\mathbf{4 a}$ and $\mathbf{4 b}$ were cross-coupled with 9-ethylcarbazole-3-boronic acid (Scheme 2). The resulting $D-A$ type small molecule donor materials $\mathbf{5 a}$ and $\mathbf{5 b}$ were isolated in high 98 and 96\% yields, respectively. The Suzuki-Miyaura cross-coupling reaction between 9-(9heptadecanyl)-2,7-bis(4,4,5,5-tetramethyl-1,3,2-dioxaborolan-2-yl)carbazole and compounds $4 \mathbf{a}$ and 4b gave the symmetrical $A-D-A$ type small molecule donor materials $6 \mathbf{a}$ and $6 \mathbf{b}$ in 96 and $78 \%$ yields, respectively. The overall yields of fluoro substituted donor materials 5a and 6a were 34 and 33\%, respectively, after seven reaction steps [38]. The total synthesis of compounds $\mathbf{5 b}$ and $\mathbf{6 b}$ were more difficult since, after six reaction steps, the overall yields were 21 and 17\%, respectively [39]. 

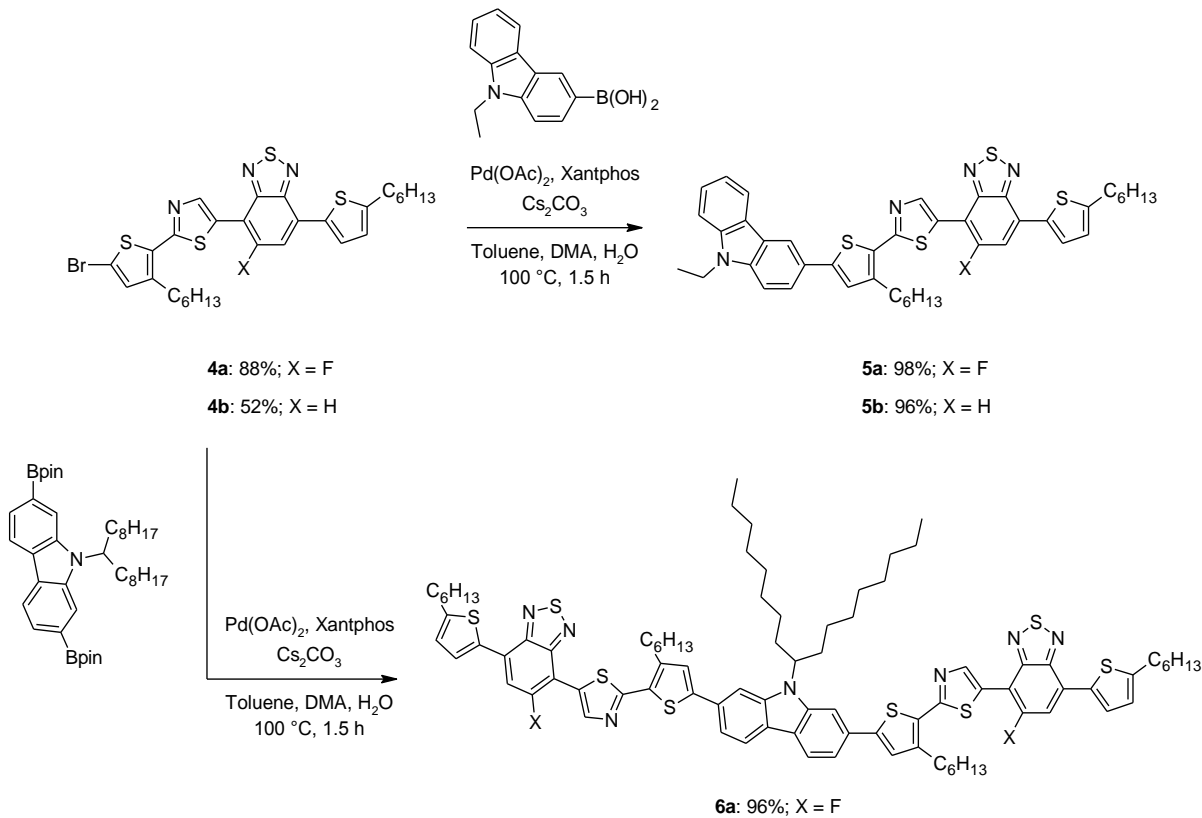

6b: $78 \% ; \mathrm{X}=\mathrm{H}$

Scheme 2. Syntheses of the $D-A$ and $A-D-A$ type small molecule donor materials

\subsection{Spectroscopic and electrochemical properties}

The experimental UV-vis absorption spectra of compounds $5 \mathbf{a}, \mathbf{5 b}, \mathbf{6} \mathbf{a}$, and $\mathbf{6 b}$ in chloroform solution, and those of thin films, normalized at the $\mathrm{S}_{0}-\mathrm{S}_{1}$ transition absorption maximum, are shown in Figures 2 (A) and (B), respectively. The calculated time-dependent density functional theory (TDDFT) solution spectra are presented in Fig. S1. The main results retrieved from the spectra have been summarized in Table 1.
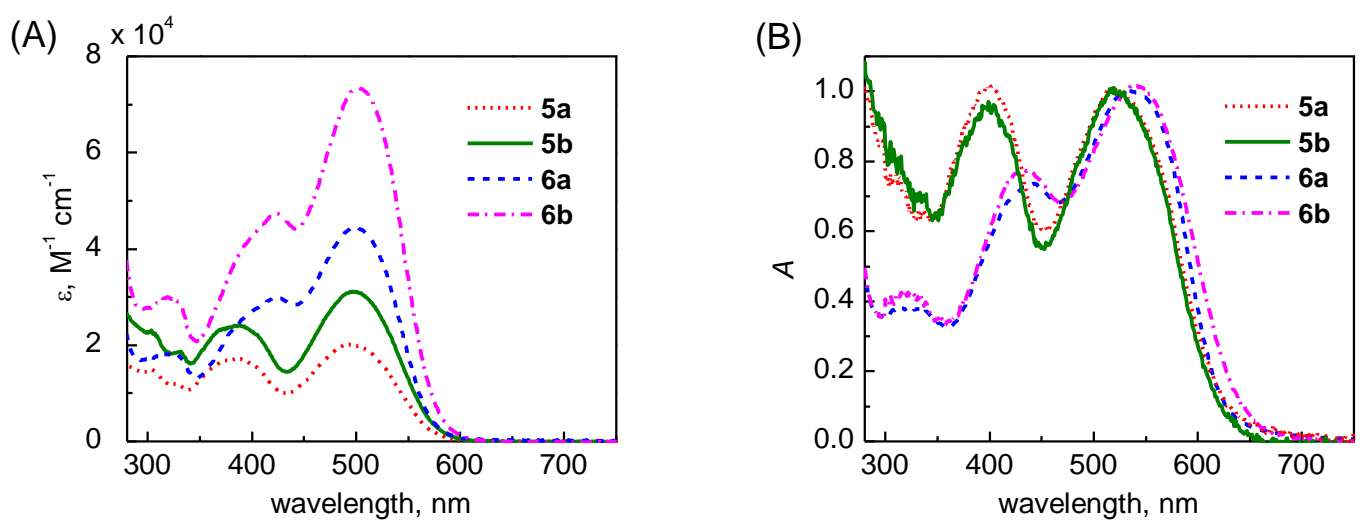

Fig. 2. (A): molar absorption coefficient $(\varepsilon)$ of compounds $\mathbf{5 a}, \mathbf{5 b}, \mathbf{6 a}$, and $\mathbf{6 b}$ in chloroform solution $(\mathrm{c}=7.5 \mu \mathrm{M})$. $(\mathrm{B})$ : normalized absorption spectra of films of the target compounds. 


\section{Table 1}

Electrochemical and spectroscopic properties of compounds $\mathbf{3 b}, \mathbf{5 a}, \mathbf{5 b}, \mathbf{6} \mathbf{a}$, and $\mathbf{6 b}$

\begin{tabular}{|c|c|c|c|c|c|c|c|c|c|}
\hline Compound & $\begin{array}{l}\text { HOMO/LUMO } \\
(\mathrm{eV})^{\mathrm{a}}\end{array}$ & $\begin{array}{l}E_{\text {gap }} \\
(\mathrm{eV})^{\mathrm{a}}\end{array}$ & $\begin{array}{l}\text { HOMO/LUMO } \\
(\mathrm{eV})^{\mathrm{b}}\end{array}$ & $\begin{array}{l}E_{\text {gap }} \\
(\mathrm{eV})^{\mathrm{b}}\end{array}$ & $\begin{array}{l}\lambda_{\max } \\
(\mathrm{nm})^{\mathrm{c}}\end{array}$ & $\begin{array}{l}\varepsilon \text { at } \lambda_{\max } \\
\left(\mathrm{M}^{-1} \mathrm{~cm}^{-1}\right)^{\mathrm{c}}\end{array}$ & $\begin{array}{l}\lambda_{\max } \\
(\mathrm{nm})^{\mathrm{d}}\end{array}$ & $\begin{array}{l}E_{\text {vert,max }} / \lambda^{e} \\
(\mathrm{eV} / \mathrm{nm})\end{array}$ & $f^{f}$ \\
\hline $3 \mathbf{b}^{\mathrm{g}}$ & $-5.49 /-3.13$ & 2.36 & - & - & 475 & 35300 & 486 & - & - \\
\hline $5 a$ & $-5.29 /-3.29$ & 2.00 & $\begin{array}{l}-5.00 /-2.73 \\
(-4.85 /-2.63)\end{array}$ & $\begin{array}{l}2.27 \\
(2.22)\end{array}$ & 495 & 20050 & $400 ; 520$ & $\begin{array}{l}2.61 / 475 \\
(2.63 / 472)\end{array}$ & $\begin{array}{l}1.40 \\
(1.17)\end{array}$ \\
\hline $5 \mathbf{b}$ & $-5.25 /-3.13$ & 2.12 & $\begin{array}{l}-5.00 /-2.69 \\
(-4.87 /-2.56)\end{array}$ & $\begin{array}{l}2.31 \\
(2.31)\end{array}$ & 499 & 31115 & $400 ; 520$ & $\begin{array}{l}2.58 / 481 \\
(2.62 / 473)\end{array}$ & $\begin{array}{l}1.41 \\
(1.22)\end{array}$ \\
\hline $6 a$ & $-5.20 /-3.16$ & 2.04 & $\begin{array}{l}-5.01 /-2.77 \\
(-4.84 /-2.69)\end{array}$ & $\begin{array}{l}2.24 \\
(2.15)\end{array}$ & 500 & 44375 & $441 ; 534$ & $\begin{array}{l}2.59 / 479 \\
(2.59 / 478)\end{array}$ & $\begin{array}{l}2.82 \\
(2.51)\end{array}$ \\
\hline $6 \mathbf{b}$ & $-5.28 /-3.27$ & 2.01 & $\begin{array}{l}-5.01 /-2.73 \\
(-4.88 /-2.63)\end{array}$ & $\begin{array}{l}2.28 \\
(2.25)\end{array}$ & 503 & 73380 & $436 ; 541$ & $\begin{array}{l}2.56 / 485 \\
(2.58 / 480)\end{array}$ & $\begin{array}{l}2.79 \\
(2.58)\end{array}$ \\
\hline
\end{tabular}

${ }^{\mathrm{a}} \mathrm{DPV}$ in dichloromethane. ${ }^{\mathrm{b}} \mathrm{Calculated}$ at the DFT/B3LYP/6-31G** level of theory in chloroform and in vacuum (in parentheses). Wavelengths correspond to the absorption maxima in ${ }^{c}$ chloroform solution $\left(7.5 \times 10^{-6} \mathrm{M}\right)$ and in ${ }^{\mathrm{d}}$ film samples, spin-coated from chloroform solution. ${ }^{\mathrm{e}}$ In chloroform and in vacuum (in parentheses); calculated at the TDDFT/ $\omega$ B97X-D/6-31G** level of theory using the B3LYP/6-31G** optimized geometries. The reported transition is for the one with the largest ${ }^{\mathrm{f}}$ oscillator strength $(f)$, i.e. absorption maximum, which corresponds to the $\mathrm{S}_{0} \rightarrow \mathrm{S}_{1}$ transition for all compounds. ${ }^{\mathrm{f}}$ Oscillator strengths calculated in chloroform and in vacuum (in parentheses). ${ }^{g}$ From reference 27.

Both the experimental and theoretically calculated absorption spectra of the four molecules in chloroform solution have very similar features with two strong, distinct bands centred at around 400 $\mathrm{nm}$ (violet band) and $500 \mathrm{~nm}$ (cyan band). The former band corresponds to a $\pi-\pi^{*}$ electronic transition of the chromophores. The latter band is attributed to intra-molecular charge transfer (ICT) from the $D$ to the $A$ moiety. This ICT is also observed theoretically in the presentation of the hole and electron natural transition orbitals (NTOs) of the main $\mathrm{S}_{0} \rightarrow \mathrm{S}_{1}$ transition (with the highest oscillator strength) calculated with TDDFT, see Table 1 and the studies of the structural and charge transfer properties below. As can be seen from Fig. 2, for all the molecules the intensity of the cyan band is higher than that of the corresponding violet band. Furthermore, for compounds $\mathbf{5 a}, \mathbf{5 b}, \mathbf{6 a}$, and $\mathbf{6 b}$, the absorption maxima are practically overlapping. Clearly, the extension of molecular structure with another $A-\pi$ unit as in compounds $\mathbf{6 a}$ and $\mathbf{6 b}$ has only a minor effect on the absorption range. The introduction of fluorine in the $A$ units, with its well-known inductive effect, is responsible for the small blue-shifts of the cyan bands in $\mathbf{5 a}$ and $\mathbf{6 a}$ relative to the non-fluorinated compounds $\mathbf{5 b}$ and $\mathbf{6 b}$. Interestingly, 
the fluoro substituent decreased notably molar absorption coefficients $(\varepsilon)$ of compounds $5 \mathbf{a}$ and $6 \mathbf{a}$ relative to the non-fluorinated counterparts $\mathbf{5 b}$ and $\mathbf{6 b}$, respectively. This effect is opposite to the previous observation of fluoro substitution in $D-A-D$ type small molecule electron donors [40]. Similarly, the TDDFT calculations predict small blue-shifts of ca. $6 \mathrm{~nm}$ for the fluorinated compounds relative to the non-fluorinated ones (Table 1, Fig. S1). Moreover, the calculated oscillator strength of the fluorinated $\mathbf{5 a}$ in chloroform is slightly decreased compared to $\mathbf{5 b}$, whereas for the symmetric $\mathbf{6 a}$ and $\mathbf{6 b}$ the opposite is predicted. By comparing the absorption properties of compounds $\mathbf{3 b}$ and $\mathbf{5 b}$, the effect of the $\mathrm{Cz}$ unit can be clearly seen: the cyan band of $\mathbf{5 b}$ is red-shifted by $24 \mathrm{~nm}$ compared to the cyan band of $\mathbf{3 b}$. However, the molar absorption coefficients are nearly the same. This result is expected, since the biggest contribution to a high $\varepsilon$ value comes from the effective conjugation between the fused BT unit and thiophene/thiazole units. The biggest difference in the absorption properties of unsymmetric compounds $\mathbf{5 a}$ and $\mathbf{5 b}$ compared to symmetric compounds $\mathbf{6} \mathbf{a}$ and $\mathbf{6} \mathbf{b}$ is that $\varepsilon$ values of the symmetrical $\mathbf{6 a}$ and $\mathbf{6 b}$ are increased notably due to their extended molecular structures. The same trend is observed in the calculated TDDFT spectra (Fig. S1), i.e. the oscillator strengths of $\mathbf{6 a}$ and $\mathbf{6 b}$ are significantly larger than those of $\mathbf{5 a}$ and $\mathbf{5 b}$ (Table 1).

In solid state spectra, the cyan bands are significantly red-shifted with respect to the cyan bands of the solution spectra, due to chromophore-chromophore intermolecular interactions in solid state. This is most evident for compounds $\mathbf{6 a}$ and $\mathbf{6 b}$ due to their extended molecular structures. The same phenomenon can be observed by comparing the solid state absorptions of compounds $\mathbf{3 b}$ and $\mathbf{5 b}$. The cyan band of $\mathbf{5 b}$ is red-shifted ( $34 \mathrm{~nm}$ ) compared to the cyan band of its building block $\mathbf{3 b}$. The $\mathrm{Cz}$ unit extends the molecular structure of $\mathbf{5 b}$ with respect to $\mathbf{3 b}$, increasing the intermolecular interactions and, thus, causing even more pronounced red-shift of absorption in solid state than in solution. The fluoro substituent does not significantly affect the intensities and the wavelengths of cyan bands of compounds $\mathbf{5 a}$ and $\mathbf{5 b}$ are equal. The cyan band of $\mathbf{6 a}$ is blue-shifted with respect to $\mathbf{6 b}$ as in solution spectra by the fluoro substituent, while the violet band of fluorinated compound $\mathbf{6 a}$ 
is red-shifted relative to non-fluorinated compound $\mathbf{6 b}$. The TDDFT calculations in vacuum predict the same trends, namely blue-shifted spectra of the fluorinated 5a and $\mathbf{6 a}$ with respect to the nonfluorinated $\mathbf{5 b}$ and $\mathbf{6 b}$. Additionally, the increased conjugation in the symmetric compounds $\mathbf{6 a}$ and $\mathbf{6 b}$ red-shifts their vacuum spectra with respect to the unsymmetric $\mathbf{5 a}$ and $\mathbf{5 b}$. The fluoro substituent decreases somewhat more the calculated oscillator strengths in $\mathbf{5 a}$ and $\mathbf{6 a}$ compared to the solvent calculations.

The electrochemical properties, i.e. the energies of the highest occupied molecular orbital (HOMO) and the lowest unoccupied molecular orbital (LUMO), of 5a, 5b, 6a, and $\mathbf{6 b}$ were determined by differential pulse voltammetry (DPV) in dichloromethane solution. In fact, the voltammograms, i.e. changes in current-voltage curves, presented with respect to the ferrocene couple in Fig. 3, clearly show reversible oxidation and reduction processes [41]. They are presented in Table 1 together with the HOMO-LUMO gap energies ( $\left.E_{\text {gap }}\right)$ and the calculated HOMO, LUMO, and gap energies in chloroform and vacuum. Electrochemical properties of the different compounds do not differ significantly. This is consistent with the observation that the absorption edges of all the compounds $\mathbf{5 a}, \mathbf{5 b}, \mathbf{6 a}$, and $\mathbf{6 b}$ locate at the same wavelength region. The HOMO energies lie in the range of -5.20 to $-5.29 \mathrm{eV}$ and the LUMO energies lie between -3.13 and $-3.29 \mathrm{eV}$. By contrast, when comparing the energy levels of $\mathbf{3 b}$ and $\mathbf{5 b}$, the extension of molecular structure of $\mathbf{5 b}$ by $\mathbf{C z}$ unit raises the HOMO energy and simultaneously narrows the $E_{\text {gap }}$ by $0.24 \mathrm{eV}$. The LUMO energy remains intact. 

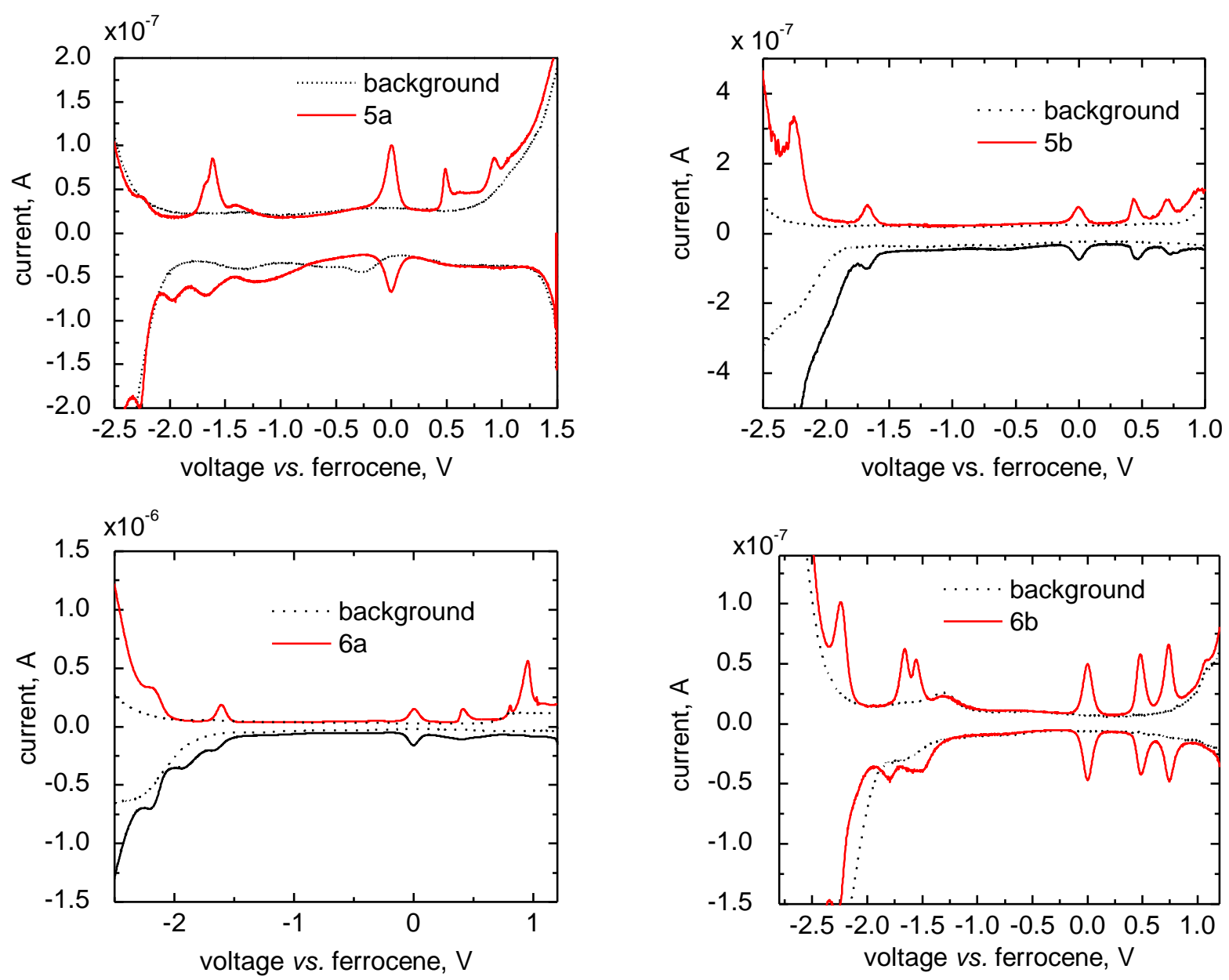

Fig. 3. DPV voltammograms of compounds $5 \mathbf{a}, \mathbf{5 b}, \mathbf{6} \mathbf{a}$, and $\mathbf{6 b}$.

\subsection{Structural and charge transfer properties}

The optimized ground-state geometries of the compounds are presented in Fig. 4. The adjoining thiophene, thiazole, and BT units are anti to each other, i.e. the sulfur atoms of the units are on the opposite sides of the molecules, in the energetically most preferable conformations of compounds 5a, 5b, 6a, and $\mathbf{6 b}$ (see Supplementary material, Fig. S2). In addition, thiophene and Cz are syn to each other in these structures, i.e. sulfur of thiophene and nitrogen of $\mathrm{Cz}$ are on the same side ( $\alpha$ in Fig. 4). Moreover, conformational studies of 5a suggest that the anti-orientation of thiophene with respect to $\mathrm{Cz}$ could also be possible, as the energy difference between these two conformations is only $0.17 \mathrm{~kJ} \mathrm{~mol}^{-1}$. In the case of the symmetrical compound $\mathbf{6 a}$, the conformational 
studies indicate that the $s y n / s y n$-orientation between thiophene and $\mathrm{Cz}$ units is more likely (by 1.25 $\mathrm{kJ} \mathrm{mol}^{-1}$ ) than the syn/anti-orientation, which may be due to the more favorable positioning of the side chains in the syn/syn-conformation. Both ${ }^{1} \mathrm{H} 1 \mathrm{D}$ and ${ }^{1} \mathrm{H}-{ }^{1} \mathrm{H} 2 \mathrm{D}$ NOE NMR data support (see Supplementary material) this prediction of the syn/syn-orientation at elevated temperatures (325-330 $\mathrm{K}$ ) in chloroform. However, it is evident that also syn/anti-orientation between thiophene and $\mathrm{Cz}$ units exists for both compounds $6 \mathbf{a}$ and $\mathbf{6 b}$ at $297 \mathrm{~K}$. On the grounds of the closest atom distances between the BT unit and the neighboring thiazole/thiophene $\pi$-bridge unit (the $\mathrm{C}-\mathrm{H} \cdots \mathrm{N}$ distance is ca. $2.3 \AA$ and the $\mathrm{C}-\mathrm{H} \cdots \mathrm{S}$ distance is $2.7 \AA$ ), there is hydrogen bonding [42] between these adjoining units. This hydrogen bonding stabilizes the structure, and planarizes the molecular backbones of all compounds for the most part in both vacuum and chloroform (Fig. S2 and Table S1). However, the steric hindrance of hydrogen atoms causes torsional twists of ca. $24-27^{\circ}$ between $\mathrm{Cz}$ and the neighboring thiophene $\pi$-bridge units ( $\alpha$ in Fig. 4). Overall, the dihedrals are only slightly smaller when calculated in chloroform instead of vacuum. On the other hand, the size of the molecule does not influence the torsions of the molecular backbones, i.e. the dihedrals of the larger symmetrical compounds $6 \mathbf{a}$ and $\mathbf{6 b}$ are very close to those in the corresponding unsymmetrical compounds $5 \mathbf{a}$ and $\mathbf{5 b}$, respectively. Moreover, the fluoro substituents of compounds 5a and 6a do not affect planarization. 

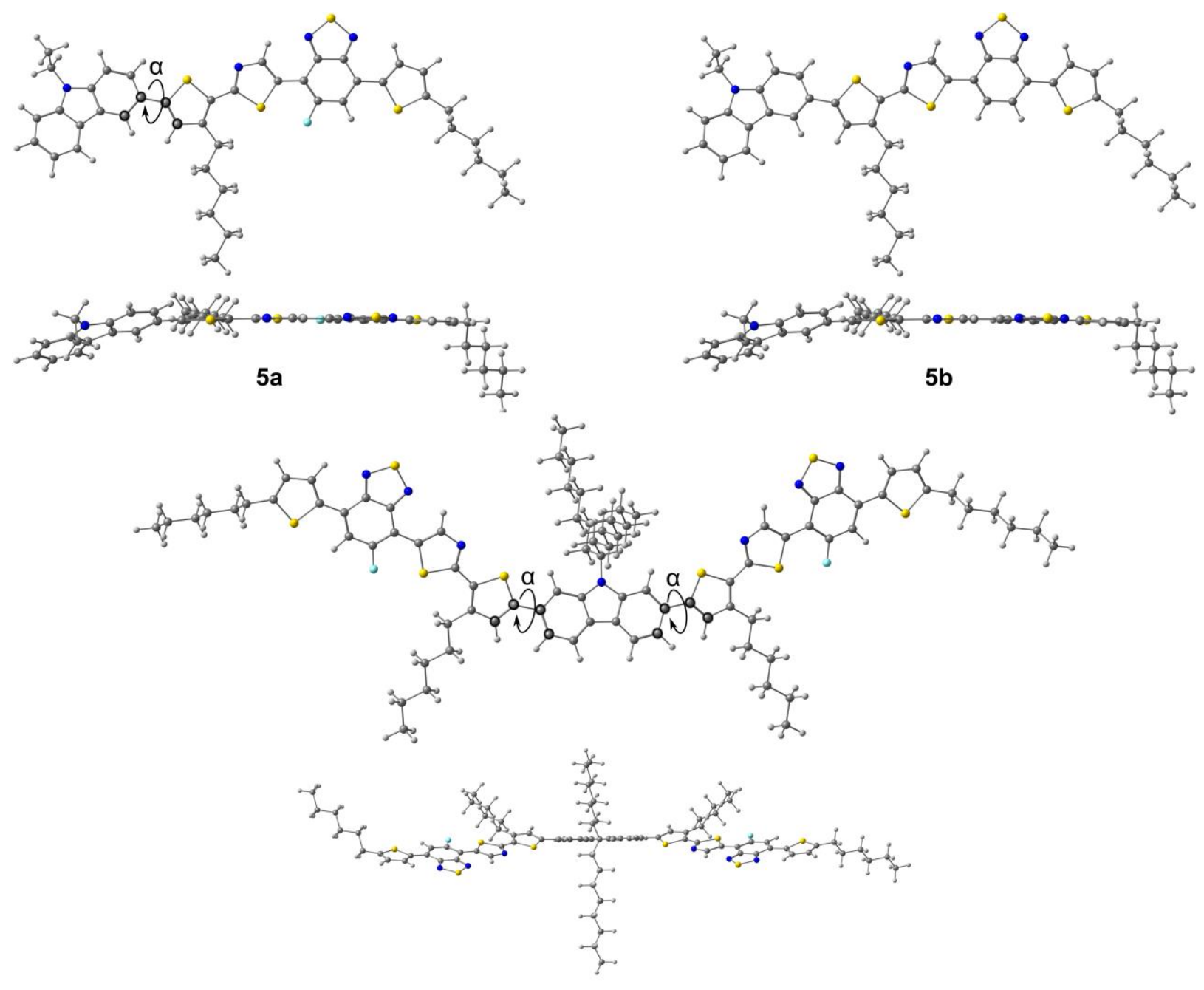

$6 a$
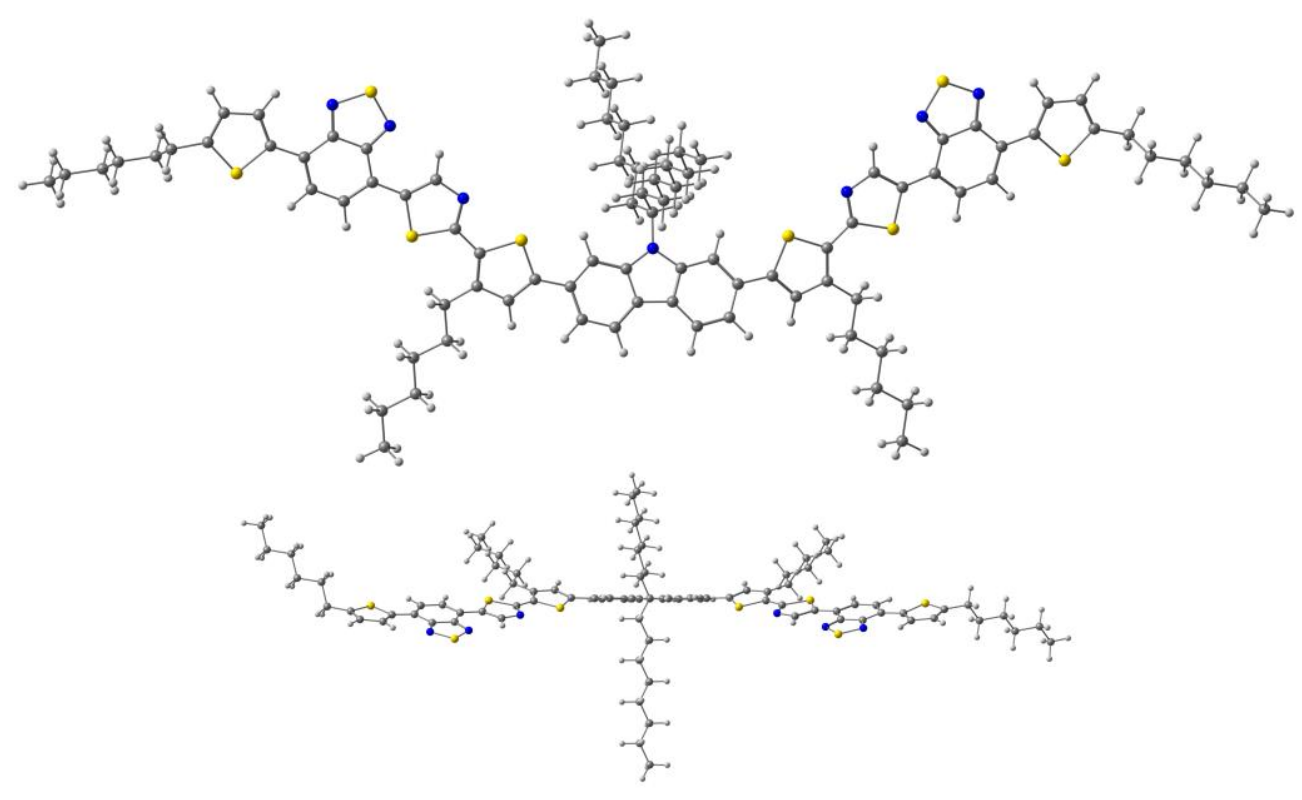

$6 b$ 
Fig. 4. Optimized ground-state geometries of compounds $\mathbf{5 a}, \mathbf{5 b}, \mathbf{6 a}$, and $\mathbf{6 b}$ calculated in chloroform at the DFT/B3LYP/6-31G** level of theory. Dihedral angles, $\alpha$, between $\mathrm{Cz}$ and thiophene in $\mathbf{5 a}$ and $\mathbf{6 a}$, are defined the same way for compounds $\mathbf{5 b}$ and $\mathbf{6 b}$.

The NTOs for the $\mathrm{S}_{0} \rightarrow \mathrm{S}_{1}$ transitions, which correspond to the main absorption peak in the theoretical UV-Vis absorption spectra calculated with the wB97X-D functional (see Supplementary material, Fig. S1), are represented in Fig. 5. The calculations predict one dominant NTO pair $\left(\lambda_{\mathrm{NTO}}\right.$ in Fig. 5) for the unsymmetrical $D-A$ type compounds $\mathbf{5 a}$ and $\mathbf{5 b}$, whereas two NTO pairs $\left(\lambda_{\mathrm{NTO}}\right.$ and $\lambda_{\mathrm{NTO} 2}$ in the figure) with almost identical contributions $(50 \%$ and $41 \%)$ are required to describe the $\mathrm{S}_{0} \rightarrow \mathrm{S}_{1}$ transition of symmetrical $A-D-A$ type compounds $\mathbf{6 a}$ and $\mathbf{6 b}$. The corresponding NTOs of 5a and $\mathbf{5 b}$ are almost identical, the only difference being a small amount of charge density localized on fluoro substituent in 5a. The same applies to $6 \mathbf{a}$ and $\mathbf{6 b}$. Moreover, all the compounds have very similar ICT character: the holes delocalize more on thiophene/thiazole units and the six-membered ring of the BT units, while the electrons localize more on the thiazole and BT units. Strikingly, the $\mathrm{Cz}$ donor unit does not participate much to the charge distribution in all cases, which is most likely due to the larger torsional twists in the backbone around it. In the symmetrical compounds $\mathbf{6 a}$ and $\mathbf{6 b}$, the charge density localizes more on the other end of the molecular backbone. The second NTO pairs of compounds $6 \mathbf{a}$ and $\mathbf{6 b}$ have the opposite charge density distributions compared to their first NTO pairs. 

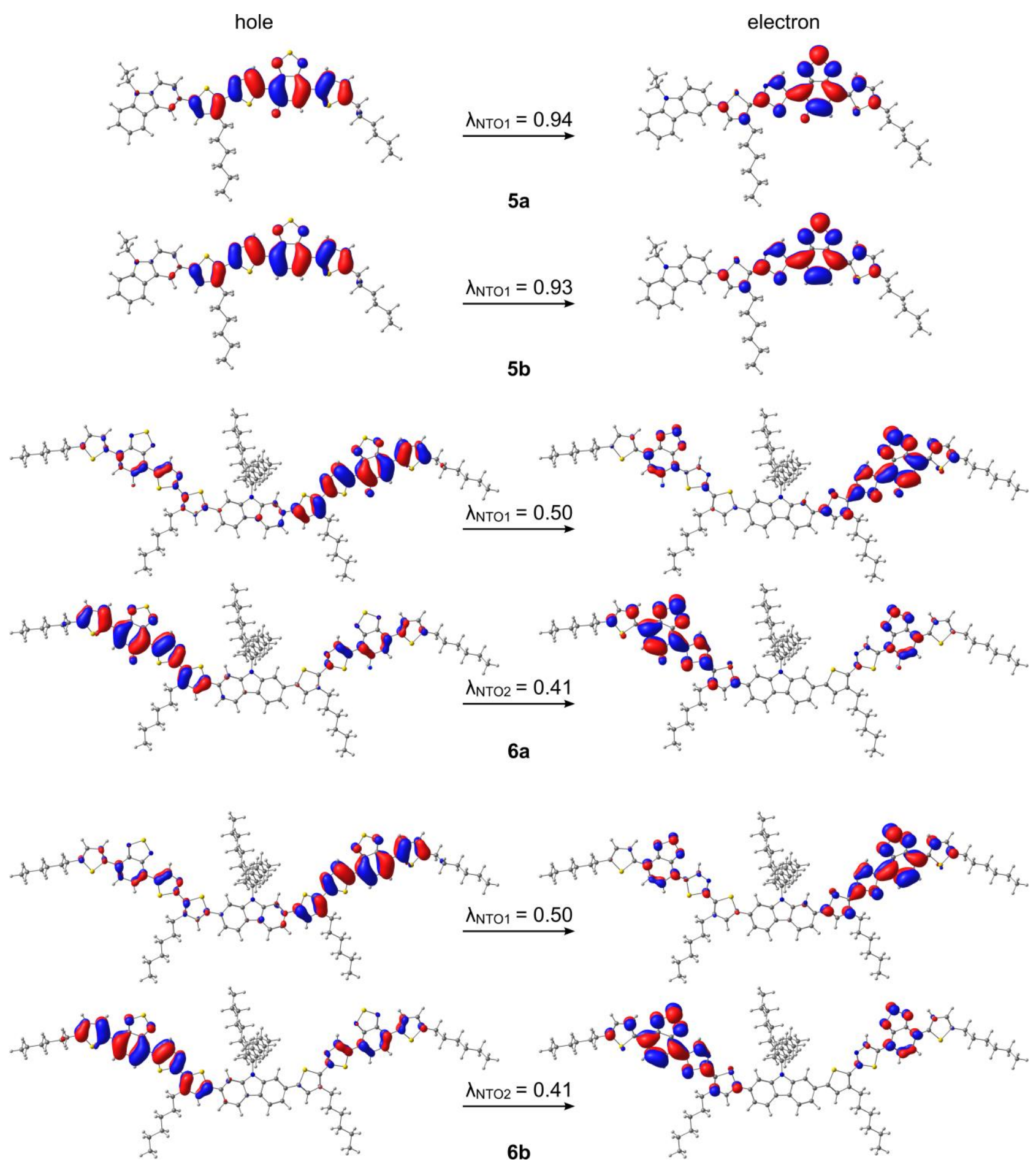

Fig. 5. NTOs for the $S_{0} \rightarrow S_{1}$ transitions of compounds $5 \mathbf{a}, \mathbf{5 b}, \mathbf{6 a}$, and $\mathbf{6 b}$ calculated at the TDDFT/ $\omega$ B $97 \mathrm{X}-\mathrm{D} / 6-31 \mathrm{G}^{* *}$ level of theory in chloroform (isodensity contour $=0.025$ ). The eigenvalue $\lambda_{\text {NTO }}$ is the fraction of the hole-electron contribution to the given transition. 


\subsection{Photovoltaics}

In order to test the potential of synthesized organic compounds as donor materials for optoelectronic applications, BHJ OSCs were prepared with conventional device structure: glass/ITO/ 5 $\mathrm{nm} \mathrm{MoO}_{3} / 80 \mathrm{~nm}$ active layer/ 20 nm Ca/ 150 nm Ag. For the active layers, donor materials $6 \mathbf{a}$ and 6b were mixed with fullerene derivatives in 1.5:1 weight ratio, respectively. $80 \mathrm{~nm}$ thick films were produced in all cases using spin-coating. Compounds $\mathbf{5 a}$ and $\mathbf{5 b}$ were omitted due to limited film forming properties. Current-voltage measurements of the best single cells in Fig. 6 demonstrate the possibility to use compounds $\mathbf{6 a}$ and $\mathbf{6 b}$ as organic electron donor materials for both type of fullerene derivatives $\left(\mathrm{PC}_{60} \mathrm{BM}\right.$ and $\left.\mathrm{PC}_{70} \mathrm{BM}\right)$. The device performances in dark demonstrate good diode characteristic with low leakage current, as shown in Fig. 6(B) and (D). When devices were illuminated with 1 sun simulated light, very good $V_{o c}(081-0.88 \mathrm{~V})$ were obtained in all cases.

The best device performances were observed using $\mathrm{PC}_{70} \mathrm{BM}$ as an electron acceptor as shown in Fig. 6(A) and (C). The device with compound 6a as an electron donor gave the highest obtained PCE of $2.80 \%$ with $V_{o c}$ of $0.88 \mathrm{~V}$, short-circuit current $\left(J_{s c}\right)$ of $5.80 \mathrm{~mA} \mathrm{~cm}{ }^{-2}$, and fill factor $(F F)$ of $55 \%$. Down the line, the fluoro substituted compound $\mathbf{6 a}$ outperformed $\mathbf{6 b}$ as a donor component, since the best observed PCE with compound $\mathbf{6 b}$ as an electron donor component (of $80 \mathrm{~nm}$ thick active layer) was $2.30 \%$, with $V_{o c}$ of $0.86 \mathrm{~V}, J_{s c}$ of $5.54 \mathrm{~mA} \mathrm{~cm}^{-2}$, and $F F$ of $48 \%$. Similar positive effect of the mono-fluoro substitution of BT unit has been previously demonstrated for $D-A-D[40]$ and more extended $D-A-D-A-D[43,44]$ type small molecule electron donors. One reason for the common positive contribution of the fluoro substituent can be the increased intermolecular interactions due to $\mathrm{C}-\mathrm{H} \cdots \mathrm{F}-\mathrm{C}$ and $\mathrm{S} \cdots \mathrm{F}-\mathrm{C}$ interactions that can lead to improved hole mobilities [44].

The limited performances of the prepared solar cell devices are mainly due to relatively low $F F$ and $J_{s c}$. The careful optimization of e.g. both solvent mixture and active layer composition would likely produce better morphologies leading to higher $F F$ s. However, the detailed optimization of OSC 
devices is not the scope of this paper. Moreover, the design of the $A-D-A$ molecular structure needs further studies, e.g. the other $D$ units should be tested to reduce the twist between the central $D$ unit and $\pi$-bridge, and to find out how this affects the performance of the compound as donor component of BHJ layer. Based on the computational studies, it seems that the twist between the central $D$ unit and $\pi$-bridge may prevent effective ICT process that can be the reason for the observed relatively low $J_{s c}$ values.
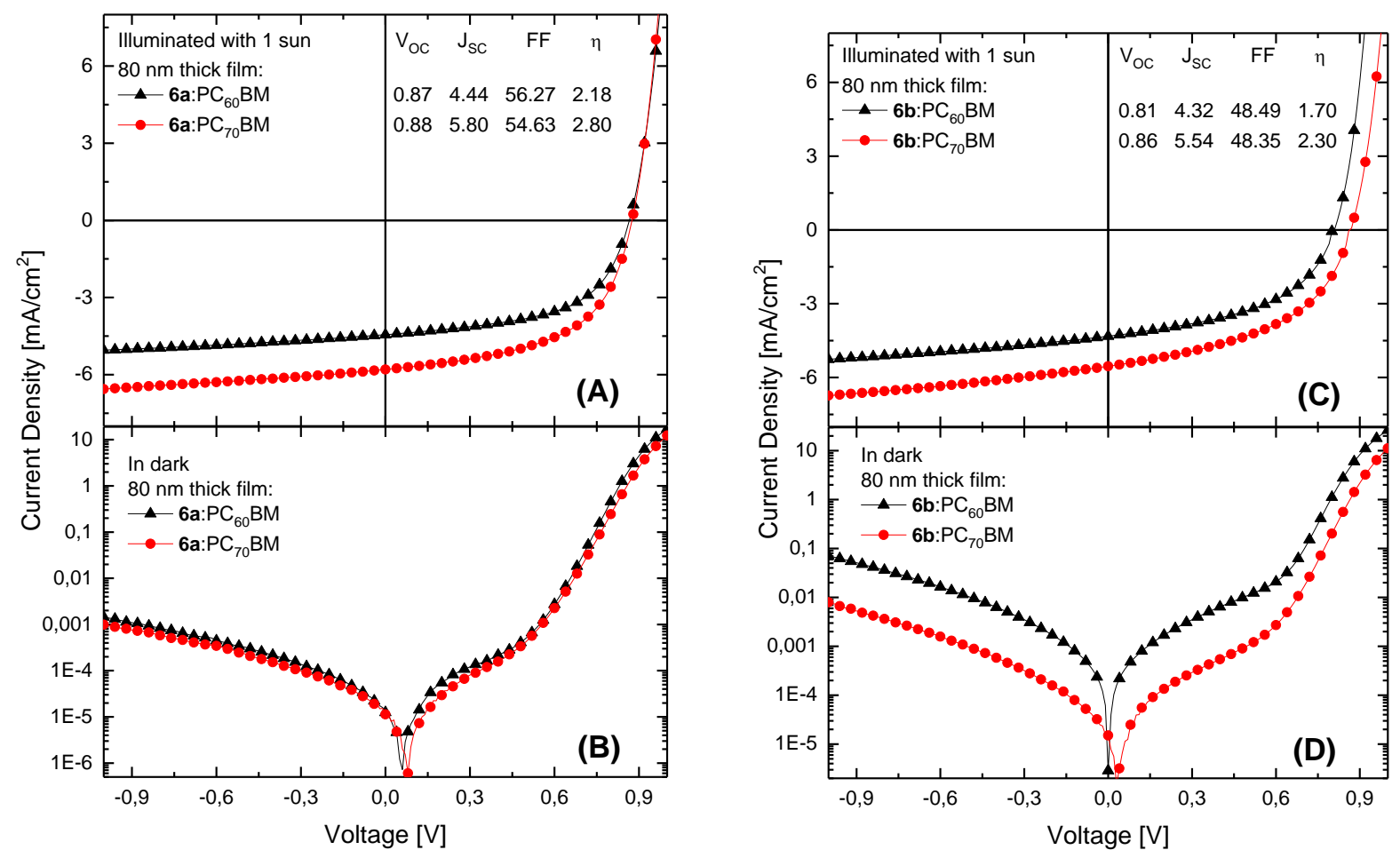

Fig. 6. Photovoltaic performance of the electron donor materials $\mathbf{6 a}$ and $\mathbf{6 b}$ mixed with different fullerene derivatives, (A) and (C) under illumination with 1 sun and (B) and (D) in dark.

\section{Conclusions}

Synthetic methods were developed to construct organic building blocks, which can be widely utilized in the syntheses of organic semiconducting materials. In this study, two $D-A$ and two $A-D-$ 
$A$ type small molecule materials were synthesized and characterized in detail. Finally, the $A-D-A$ type materials were tested as donor components in BHJ-based OSC devices.

Results show clearly that both $D-A$ and $A-D-A$ type compounds have many similar material properties, e.g. the HOMO/LUMO energies of these two compound types differ only slightly. Also, the compounds have very similar nearly planar conformations. On the other hand, the symmetric $A-$ $D-A$ type materials $6 \mathbf{a}$ and $\mathbf{6 b}$ have several advantages over the unsymmetric $D-A$ type materials $5 \mathbf{a}$ and $\mathbf{5 b}$. For example, the extended molecular structure of the $A-D-A$ type materials provides higher molar absorption coefficients and good film forming properties. These are crucial factors for efficient use of these materials in semiconducting applications. In solar cell tests, the fluoro substituent of compound $\mathbf{6 a}$ is responsible for the enhanced device performance (especially due to the increased $F F$ ), when comparing compounds $6 \mathbf{a}$ and $\mathbf{6 b}$ as donors with both $\mathrm{PC}_{60} \mathrm{BM}$ and $\mathrm{PC}_{70} \mathrm{BM}$ acceptors. However, to fully optimize the structures of the $A-D-A$ type materials, other central $D$ units should be tested, to prevent the undesired twist of the molecular structures between the central $D$ unit and the $\pi$-bridge. In this way, more effective conjugation and decreased $E_{\text {gap }}$ values may be achieved. Small molecule donor materials with a narrower bandgap would cover a broader range of the solar spectrum and increase the total absorption leading to increased photo-current. All these factors are beneficial for the material performance as an active layer component in a BHJ-based OSC device.

\section{Acknowledgements}

The authors thank Mrs. Päivi Joensuu for HRMS data. Magnus Ehrnrooth Foundation is greatly acknowledged for funding by R.J.S. and J.P.H. Academy of Finland (Decision No. 268672) is acknowledged for the financial support by P.V. Graduate School of Tampere University of Technology (TUT) and the Finnish Cultural Foundation is acknowledged for funding by T.K.

\section{Supplementary Material}


Supplementary data related to this article can be found at

\section{References and Footnotes}

[1] J. Roncali, Acc. Chem. Res., 2009, 42, 1719-1730.

[2] B. Walker, C. Kim, T.-Q. Nguyen, Chem. Mater., 2010, 23, 470-482.

[3] A. K. K. Kyaw, D. H. Wang, V. Gupta, J. Zhang, S. Chand, G. C. Bazan, A. J. Heeger, Adv. Mater., 2013, 25, 2397-2402.

[4] A. Mishra, P. Bäuerle, Angew. Chem., Int. Ed., 2012, 51, 2020-2067.

[5] T. S. van der Poll, J. A. Love, T.-Q. Nguyen, G. C. Bazan, Adv. Mater., 2012, 24, 3646-3649.

[6] A. K. K. Kyaw, D. H. Wang, V. Gupta, W. L. Leong, L. Ke, G. C. Bazan, A. J. Heeger, ACS Nano, 2013, 7, 4569-4577.

[7] Y. Sun, G. C. Welch, W. L. Leong, C. J. Takacs, G. C. Bazan, A. J. Heeger, Nat. Mater., 2012, $11,44-48$

[8] W. Ni; X. Wan, M. Li, Y. Wang, Y. Chen, Chem. Commun., 2015, 51, 4936-4950.

[9] A. K. K. Kyaw, D. H. Wang, D. Wynands, J. Zhang, T.-Q. Nguyen, G. C. Bazan, A. J. Heeger, Nano Lett., 2013, 13, 3796-3801.

[10] M. Cheng, C. Chen, X. Yang, J. Huang, F. Zhang, B. Xu, L. Sun Chem. Mater., 2015, 27, 18081814.

[11] Y. Liu, J. Zhao, Z. Li, C. Mu, W. Ma, H. Hu, K. Jiang, H. Lin, H. Ade, H. Yan, Nat. Commun., 2014, doi: 10.1038/ncomms6293.

[12] J. Du, M. C. Biewer, M. C. Stefan, J. Mater. Chem. A, 2016, 4, 15771-15787.

[13] H. Zhou, L. Yang, W. You, Macromolecules, 2012, 45, 607-632.

[14] D. Gendron, M. Leclerc, Energy Environ. Sci., 2011, 4, 1225-1237. 
[15] G. Sathiyan, E. K. T. Sivakumar, R. Ganesamoorthy, R. Thangamuthu, P. Sakthivel, Tetrahedron Lett., 2016, 57, 243-252.

[16] S. H. Park, A. Roy, S. Beaupré, S. Cho, N. Coates, J. S. Moon, D. Moses, M. Leclerc, K. Lee, A. J. Heeger, Nat. Photon., 2009, 3, 297-302.

[17] P. Li, H. Tong, J. Ding, Z. Xie, L. Wang, J. Mater. Chem. A, 2013, 1, 8805-8812.

[18] P. Li, H. Tong, J. Liu, J. Ding, Z. Xie, L. Wang, RSC Adv., 2013, 3, 23098-23104.

[19] M. Li, W. Ni, H. Feng, X. Wan, Y. Liu, Y. Zuo, B. Kan, Q. Zhang, Y. Chen, Org. Electron., 2015, 24, 89-95.

[20] N. Sylvianti, Y. W. Kim, M. A. Marsya, D. K. Moon, J. H. Kim, Synth. Met., 2016, 221, 127133.

[21] C.-Y. Huang, W.-H. Lee, R.-H. Lee, RSC Adv., 2014, 4, 48150-48162.

[22] T. Jadhav, R. Misra, S. Biswas, G. D. Sharma, Phys. Chem. Chem. Phys., 2015, 17, 2658026588.

[23] M. A. Reddy, CH. Pavan Kumar, A. Ashok, A. Sharma, G. D. Sharma, M. Chandrasekharam, RSC Adv., 2016, 6, 9023-9036.

[24] D. Dang, P. Zhou, M. Xiao, R. Yang, W. Zhu, Dyes Pigm., 2016, 133, 1-8.

[25] Q. Wang, L. Duan, Q. Tao, W. Peng, J. Chen, H. Tan, R. Yang, W. Zhu, ACS Appl. Mater. Interfaces, 2016, 8, 30320-30327.

[26] Y. Patil, R. Misra, F. C. Chen, G. D. Sharma, Phys. Chem. Chem. Phys., 2016, 18, 22999-23005. [27] J. P. Heiskanen, P. Vivo, N. M. Saari, T. I. Hukka, T. Kastinen, K. Kaunisto, H. J. Lemmetyinen, O. E. O. Hormi, J. Org. Chem., 2016, 81, 1535-1546.

[28] This alkyl region integral can be received from ${ }^{1} \mathrm{H}$ spectrum recorded at $297 \mathrm{~K}$ (see Supplementary material).

[29] M. Sailer, A. W. Franz and T. J. J. Müller, Chem. - A Eur. J., 2008, 14, 2602-2614. 
[30] B. W. D’Andrade, S. Datta, S. R. Forrest, P. Djurovich, E. Polikarpov and M. E. Thompson, Org. Electron. physics, Mater. Appl., 2005, 6, 11-20.

[31] M. J. Frisch, G. W. Trucks, H. B. Schlegel, G. E. Scuseria, M. A. Robb, J. R. Cheeseman, G. Scalmani, V. Barone, B. Mennucci, G. A. Petersson, H. Nakatsuji, M. Caricato, X. Li, H. P. Hratchian, A. F. Izmaylov, J. Bloino, G. Zheng, J. L. Sonnenberg, M. Hada, M. Ehara, K. Toyota, R. Fukuda, J. Hasegawa, M. Ishida, T. Nakajima, Y. Honda, O. Kitao, H. Nakai, T. Vreven, J. A. Montgomery, Jr., J. E. Peralta, F. Ogliaro, M. Bearpark, J. J. Heyd, E. Brothers, K. N. Kudin, V. N. Staroverov, R. Kobayashi, J. Normand, K. Raghavachari, A. Rendell, J. C. Burant, S. S. Iyengar, J. Tomasi, M. Cossi, N. Rega, J. M. Millam, M. Klene, J. E. Knox, J. B. Cross, V. Bakken, C. Adamo, J. Jaramillo, R. Gomperts, R. E. Stratmann, O. Yazyev, A. J. Austin, R. Cammi, C. Pomelli, J. W. Ochterski, R. L. Martin, K. Morokuma, V. G. Zakrzewski, G. A. Voth, P. Salvador, J. J. Dannenberg, S. Dapprich, A. D. Daniels, Ö. Farkas, J. B. Foresman, J. V. Ortiz, J. Cioslowski, and D. J. Fox, Gaussian 09, Revision D.01, Gaussian, Inc., Wallingford CT, 2009.

[32] A. D. Becke, J. Chem. Phys., 1993, 98, 5648-5652.

[33] C. Lee, W. Yang and R. G. Parr, Phys. Rev. B, 1988, 37, 785-789.

[34] Cancès, E.; Mennucci, B.; Tomasi, J. J. Chem. Phys. 1997, 107, 3032-3041.

[35] Mennucci, B.; Cancès, E.; Tomasi, J. J. Phys. Chem. B 1997, 101, 10506-10517.

[36] Martin, R. L. J. Chem. Phys. 2003, 118, 4775-4777.

[37] L. F. Lai, J. A. Love, A. Sharenko, J. E. Coughlin, V. Gupta, S. Tretiak, T.-Q. Nguyen, W.-Y Wong, G. C. Bazan, J. Am. Chem. Soc., 2014, 136, 5591-5594.

[38] The synthesis of 2-(3-hexylthiophen-2-yl)-5-(4,4,5,5-tetramethyl-1,3,2-dioxaborolan-2yl)thiazole takes three reaction steps and the compound can be prepared in $57 \%$ overall yield. See reference 27.

[39] The synthesis of compound $\mathbf{3 b}$ takes four reaction steps and the compound can be isolated in $43 \%$ overall yield. See reference 27. 
[40] N. Cho, K. Song, J. K. Lee, J. Ko, Chem. Eur. J., 2012, 18, 11433-11439.

[41] L. E. Lyons, Aust J. Chem. 1980, 33, 1717-1725.

[42] N. E. Jackson, B. M. Savoie, K. L. Kohlstedt, M. O. de la Cruz, G. C. Schatz, L. X. Chen, M. A. Ratner, J. Am. Chem. Soc., 2013, 135, 10475-10483.

[43] X. Liu, S. Li, J. Li, J. Wang, Z. Tan, F. Yan, H. Li, Y. H. Lo, C.-H. Chui, W.-Y. Wong, RSC Adv., 2014, 4, 63260-63267.

[44] J. Sim, K. Do, K. Song, A. Sharma, S. Biswas, G. D. Sharma, J. Ko, Org. Electron., 2016, 30, $122-130$. 